\title{
Wetland vegetation from the Miocene deposits of the Bełchatów Lignite Mine (central Poland)
}

\author{
Grzegorz Worobiec and Elżbieta Worobiec
}

\begin{abstract}
Fossil plant remains (mainly leaves) of 18 species from the genera Acer, Alnus, Betula, Carpinus, Carya, cf. Cercidiphyllum, Dicotylophyllum, Fagus, Gleditsia, Laria, Leguminophyllum, Myrica, Phragmites, Pinus, Potamogeton, and Sequoia were found in upper Miocene deposits of the Bełchatów Lignite Mine (Central Poland). The fossil assemblage KRAM-P 225 is dominated by plant remains of bottomland forest type riparian vegetation. Some taxa point to the presence of water body and mesophytic upland communities. The composition of the fossil plant assemblage suggests warm temperate and moderately wet climatic conditions, comparable to the Cfa climate type (warm temperate, fully humid with hot summer) in the Köppen-Geiger climate classification. The mean annual temperature of $13.5^{\circ} \mathrm{C}-16.5^{\circ} \mathrm{C}$ was estimated by the coexistence approach method on the basis of plant macroremains. The deposits bearing these fossils are considered to be of latest middle Miocene to late Miocene age.
\end{abstract}

Grzegorz Worobiec. W. Szafer Institute of Botany, Polish Academy of Sciences, Lubicz 46, PL-31-512 Kraków, Poland. g.worobiec@botany.pl

Elżbieta Worobiec. W. Szafer Institute of Botany, Polish Academy of Sciences, Lubicz 46, PL-31-512

Kraków, Poland. e.worobiec@botany.pl

Keywords: fossil leaves; new species; palaeovegetation; palaeoclimate; Neogene; Central Europe

Submission: 26 March 2018. Acceptance: 23 September 2019.

\section{INTRODUCTION}

Lignite deposits exploited by the Bełchatów Lignite Mine (central Poland) are amongst the largest Neogene lignite deposits in Europe mined for power plant industry purposes. They were discovered as a result of a geological investigation at the beginning of the 1960s (Stuchlik et al., 1990). Neogene alluvial sediments with lignite seams that fill the tectonic depression named the Kleszczów Graben contain plant macro- and microremains. From 1960 to 1977 only palynological investigations of Neogene deposits from the Bełchatów mine were carried out. Ziembińska-Tworzydło (1966) consid-

Worobiec, Grzegorz and Worobiec, Elżbieta. 2019. Wetland vegetation from the Miocene deposits of the Bełchatów Lignite Mine (central Poland). Palaeontologia Electronica 22.3.63 1-38. https://doi.org/10.26879/871 palaeo-electronica.org/content/2019/2761-miocene-vegetation-of-poland

Copyright: October 2019 Paleontological Society.

This is an open access article distributed under the terms of Attribution-NonCommercial-ShareAlike 4.0 International (CC BY-NC-SA 4.0 ), which permits users to copy and redistribute the material in any medium or format, provided it is not used for commercial purposes and the original author and source are credited, with indications if any changes are made.

creativecommons.org/licenses/by-nc-sa/4.0/ 
ered the main coal seam to be of middle Miocene age based on palynological investigations. Starting from 1977, comprehensive palaeobotanical investigations of plant macroremains were carried out in the exposure. The results of investigations of plant macro- and microremains performed from 1977 to 1990 were summarised by Stuchlik et al. (1990). They established the age of deposits filling the Kleszczów Graben as Neogene, the main coal seam as late Miocene, and the overburden deposits as late Miocene-Pliocene (Stuchlik et al., 1990). Palaeobotanical investigations of the assemblages of plant macroremains from the Bełchatów Lignite Mine were then continued (Wójcicki and Zastawniak, 1998; Worobiec and Lesiak, 1998; Otto et al., 2001; Worobiec, 2003b; Worobiec and Worobiec, 2005; Worobiec, 2007; Worobiec and Szynkiewicz, 2007; Worobiec and Worobiec, 2008; Worobiec et al., 2012; Worobiec, 2014; Worobiec and Szynkiewicz, 2016; Worobiec and Worobiec, 2016). Besides fossil plant remains, fossil insects (Wegierek, 1995), snails (Stworzewicz and Szynkiewicz, 1988; Stworzewicz, 1995), freshwater fishes (Jerzmańska and Hałuszczak, 1986), and mammals (Kowalski, 1993; Rzebik-Kowalska and Kowalski, 2001; Kowalski and Rzebik-Kowalska, 2002) preserved in the Neogene infilling of Kleszczów Graben were investigated.

During the investigations of Neogene deposits exposed in the Bełchatów Lignite Mine in October 1996, an interesting fossil leaf assemblage was found, although it has not yet been fully studied. Only the remains of Malvaceae sensu lato preserved in the discussed assemblage (fossil leaves of Laria rueminiana (Heer) G. Worobiec and Kvaček) were investigated (Worobiec et al., 2010). The very good state of preservation of the plant fossils allows extensive palaeofloristical studies of the leaf remains. The current investigations are aimed at a comprehensive analysis of the palaeofloristics of the fossil assemblage followed by reconstruction of palaeovegetation. The results obtained form the basis for palaeoclimatic reconstructions and discussion of the age of the fossil assemblage. Data obtained by investigations of the discussed fossil plant assemblages from the Bełchatów mine contribute to reconstructing the Neogene flora and vegetation of Poland and to assessing and to documenting the biodiversity of Central Europe during the Neogene period.

\section{GEOLOGY}

Bełchatów Lignite Mine is situated in central Poland $\left(51^{\circ} 15^{\prime} 46.4^{\prime \prime} \mathrm{N} 19^{\circ} 18^{\prime} 49.2^{\prime \prime} \mathrm{E}\right)$, south of the town of Bełchatów (Figure 1). Neogene deposits with lignite seams occur within tectonic depressions of the Kleszczów Graben (Stuchlik et al., 1990). Four lithological units (subcoal unit [PW], coal unit [W], clayey-coal unit [I-W], and clayeysandy unit [I-P]; Figure 2) were distinguished in the Neogene sedimentary series of the Kleszczów Graben (Czarnecki et al., 1992; Matl, 2000). The discussed leaf assemblage was found on October 24,1996 , in the Neogene deposits of the overburden escarpment 3 on the western slope of the open pit of the Bełchatów Lignite Mine, near spans 100-110 of conveyor belt B-302, southwest to borehole no. 1315. In the floor of the profile of the plant-bearing deposits were sands, clayey sands, and sandy clays covered by an erosional layer of flintstones and sands. The clay layer on top of this level contained the discussed plant assemblage covered by sands with silts. The discussed deposits belong to the clayey-sandy (I-P) unit considered to be of late Miocene age (Burchart et al., 1988; Stuchlik et al., 1990; Kowalski, 1993; Szynkiewicz, 2000; Kowalski and Rzebik-Kowalska, 2002).

Wilczyński (1992) and Krzyszkowski and Winter (1996) considered the sedimentary series of the lower part of the clayey-sandy unit as having been formed in a fluvial environment of braided to meandering rivers with lush vegetation along the river banks.

\section{MATERIAL AND METHODS}

Fossil leaves from the discussed assemblage are preserved both as compressions and impressions. The best-preserved leaf compressions were isolated from the rock matrix and mounted on glass slides following the procedure described by Woro-

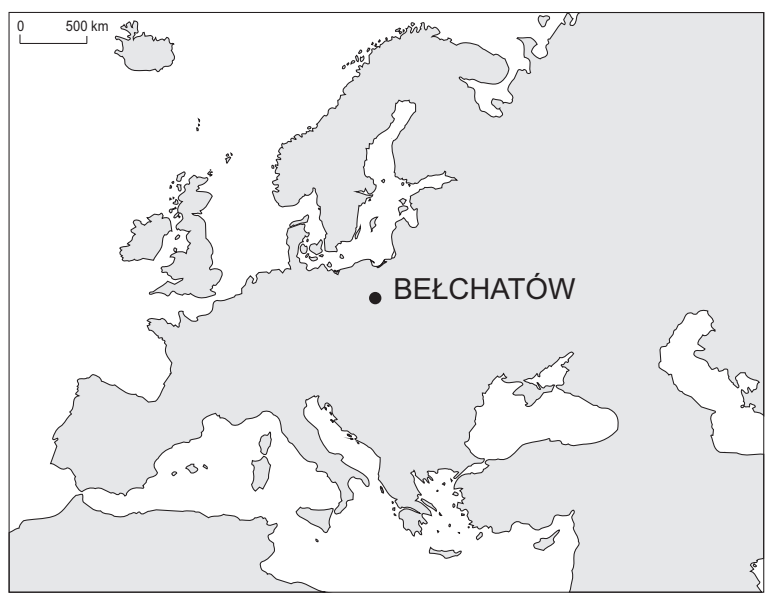

FIGURE 1. Location of the Bełchatów Lignite Mine. 


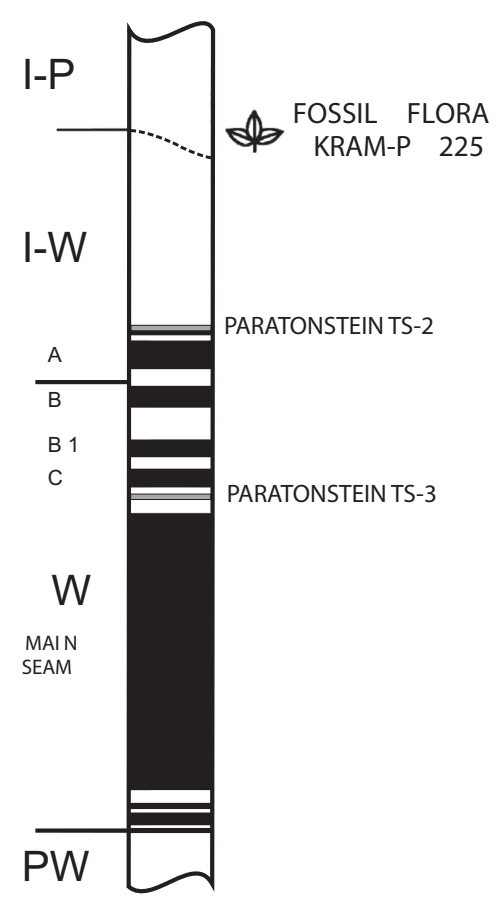

FIGURE 2. Schematic geological profile of Neogene deposits of the Bełchatów Lignite Mine (modified after Worobiec, 2007). PW, subcoal unit; W, coal unit; I-W, clayey-coal unit; I-P, clayey-sandy unit; A, B, B1, C, other coal seams. Black pattern, coal seams; grey pattern, paratonsteins (tuffaceous horizons).

biec (2003a). Thirty-seven slides of isolated leaves were made.

The remaining fossil leaves were slowly dried. In the case of isolated leaves and selected leaf compressions, small fragments of leaf blades were taken for cuticular analysis. These fragments were then cleaned with hydrofluoric acid, washed in water, macerated using $\mathrm{NaClO}$ solution (Bielnar commercial bleach), and finally mounted on slides with glycerine jelly. Altogether, 61 cuticular slides were made. All of the studied fossil leaves as well as the cuticular slides are housed in the W. Szafer Institute of Botany, Polish Academy of Sciences (Kraków) under catalogue number KRAM-P 225. The total number of specimens of all taxa is greater than the total number of rock samples with plant remains because in many cases remains belonging to different taxa were preserved in one rock sample. In such cases an alphanumerical specimen number is used. In total, 95 samples were studied.

Macromorphological descriptions of leaves mostly follow Hickey $(1973,1979)$ and Ellis et al. (2009), and micromorphological cuticular descriptions follow Dilcher (1974) and Wilkinson (1979). Macroscopic objects (specimens) were measured with a ruler while microscopic ones (epidermal structures) were measured using microscope eyepiece with a scale (reticle). The measurements taken on the epidermal structures (e.g., cells, stomata) depended on their shape. The diameter was measured for round or broadly elliptic objects, while the length and width were used for all roughly rectangular objects. For objects of irregular shape (mainly epidermal cells) the longest dimension was measured. Macrophotographs were taken with a Nikon Coolpix 995 digital camera and a Nikon SMZ 800 stereomicroscope fitted with a Nikon DS-5M-U1 digital camera. Microphotographs were taken with a Nikon Eclipse E400 microscope fitted with a Canon A640 digital camera.

For palynological analysis eight samples from clays, containing the plant macroremains of the KRAM-P 225 collection, were taken. The palynological samples were processed in the Laboratory of the W. Szafer Institute of Botany, PAS, using hydrochloric acid and sulfuric acid (Moore et al., 1991). Additionally, hydrofluoric acid was used to remove mineral matter and the residuum was sieved at $5 \mu \mathrm{m}$ on a nylon mesh. From each sample, microscope slides were made, using glycerine jelly as a mounting medium. In each sample, more than 600 pollen grains and spores were identified, and for this purpose, one to three microscope slides were studied from each sample. The palynological residues and slides are stored in the $\mathrm{W}$. Szafer Institute of Botany, PAS (Kraków).

\section{SYSTEMATIC PALAEOBOTANY}

The classification for gymnosperms follows Christenhusz et al. (2011), and for angiosperms and the author names of their families, it follows APG IV (2016), the IPNI (2018), and Farr and Zijlstra (2018). Plant families, genera, and species are listed following Chase and Reveal (2009), Haston et al. (2009), and Christenhusz et al. (2011).

Clade ACROGYMNOSPERMAE Cantino and

Donoghue, 2007, in Cantino et al. (2007)

Family PINACEAE Sprengel ex F. Rudolphi, 1830 Genus PINUS Linnaeus, 1753

Type species. Pinus sylvestris Linnaeus, 1753

Pinus sp.

Figures 3.5, 4.1

\section{Description}

Macromorphology. Two fragments (up to $6 \mathrm{~cm}$ ) of exfoliated bark.

Micromorphology. Cell walls strongly undulate, sclerenchymatic, rather thick. 

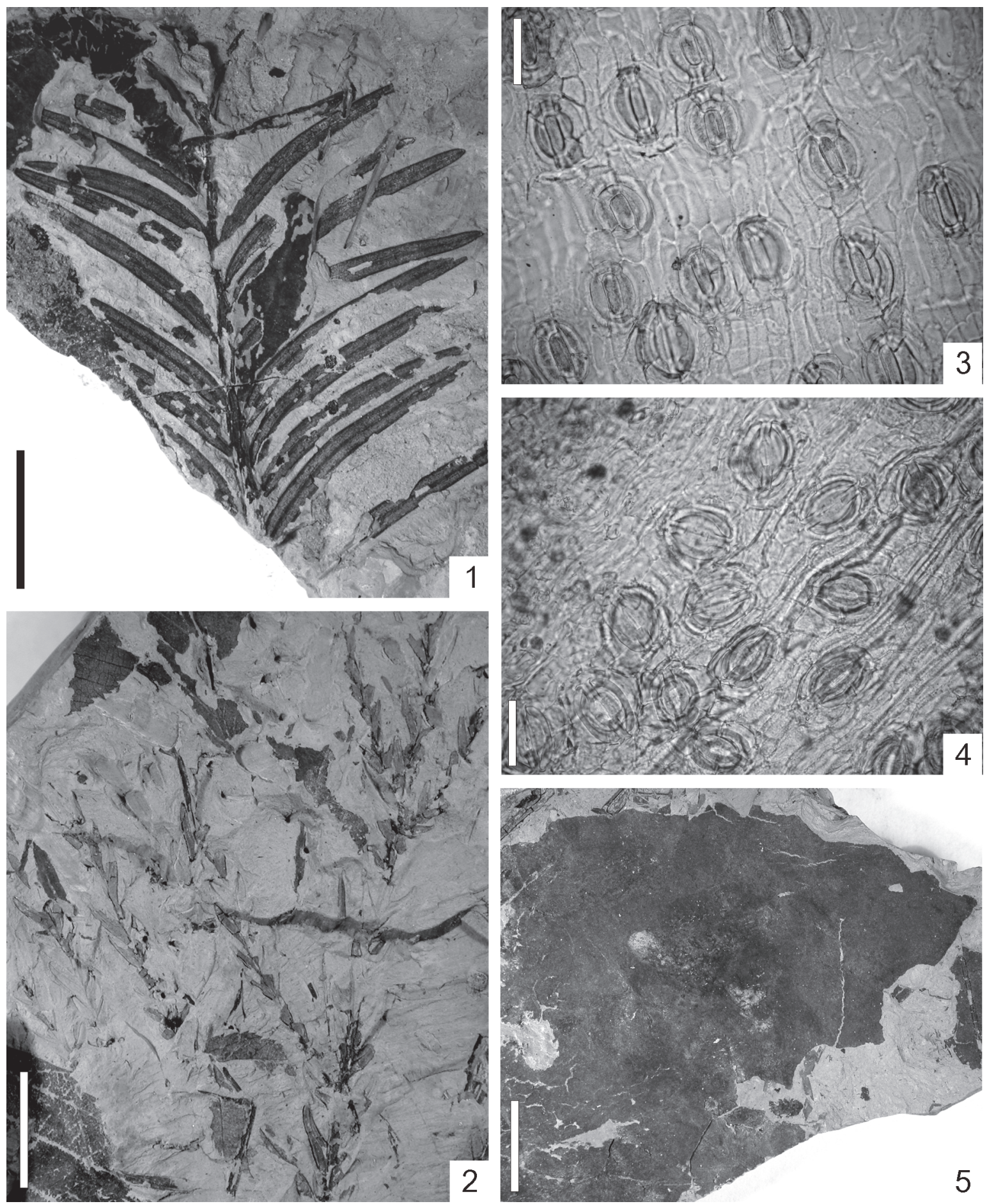

FIGURE 3. Sequoia abietina (Brongniart) Knobloch: 1. Taxodioid twig, KRAM-P 225/108; 2. Cryptomerioid twig, KRAM-P 225/86/VII; 3. Epidermis of needle from taxodioid twig, note parallel arrangement of longer axes of stomata in stomatal rows, KRAM-P 225/115; 4. Epidermis of needle from cryptomerioid twig, note variable arrangement of longer axes of stomata in stomatal rows, KRAM-P 225/86/VII. Pinus sp.: 5. Bark fragment, KRAM-P 225/99/Il. Scale bar equals to $1 \mathrm{~cm}$ for (1), (2), and (5), and $50 \mu \mathrm{m}$ for (3) and (4). 

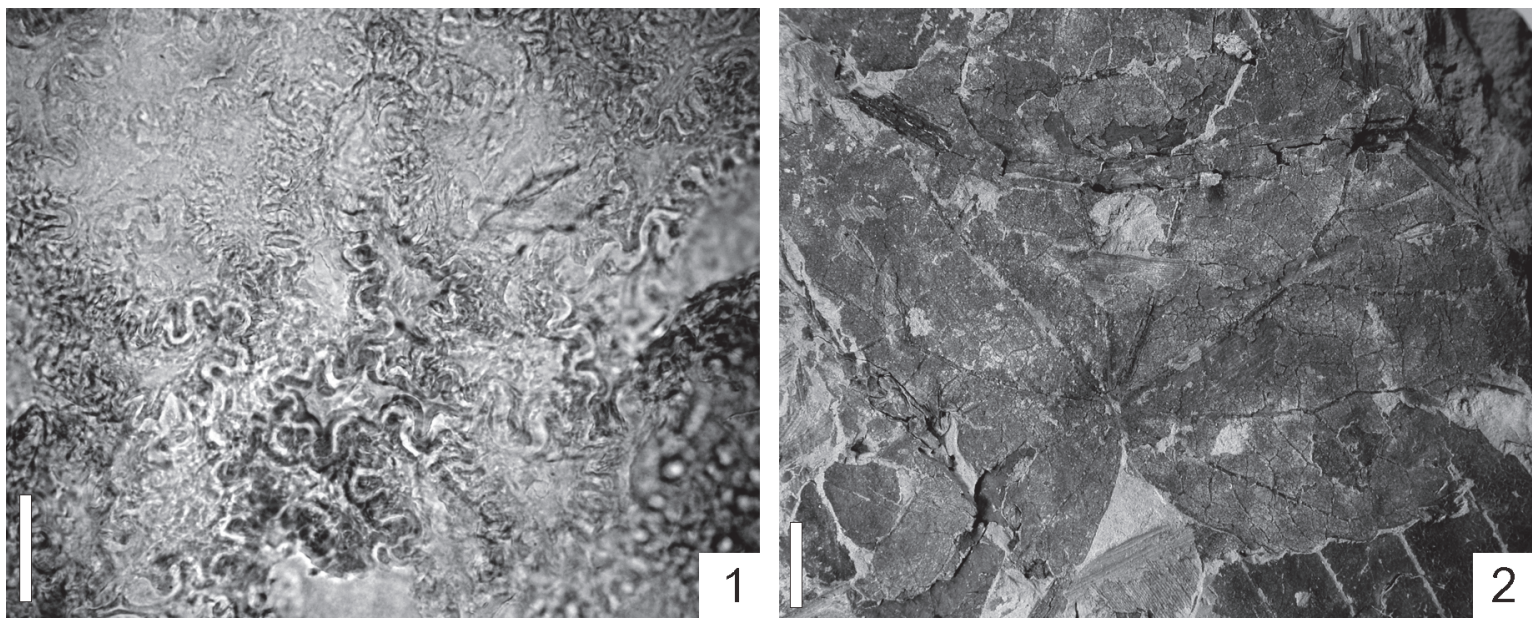

FIGURE 4. Pinus sp.: 1. Sclerenchymatic cells of bark, KRAM-P 225/99/II. cf. Cercidiphyllum crenatum (Unger) R. W. Brown emend. Z. Kvaček and Konzalová: 2. Leaf fragment, KRAM-P 225/44/II. Scale bar equals to $0.5 \mathrm{~cm}$ for (2), and $50 \mu \mathrm{m}$ for (1).

\section{Specimens examined}

KRAM-P 225: 48/II, 99/II.

\section{Remarks}

These plant remains represent the peeled bark of Pinus. Worobiec (2014) and Worobiec and Szynkiewicz (2016) reported the same type of exfoliated bark of Pinus associated with the needles of Pinus $\mathrm{sp}$. from late Miocene leaf assemblages from the Bełchatów mine.

\section{Family CUPRESSACEAE Gray, 1821 Genus SEQUOIA Endlicher, 1847}

Type species. Sequoia sempervirens (D. Don) Endlicher, 1847

\section{Sequoia abietina (Brongniart) Knobloch, 1964} Figure 3.1-4

\section{Description}

Macromorphology. Shoots trimorphous. Taxodioid shoots bearing flat, entire-margined needles with distinctly marked midvein, up to 3.1 (rarely to $3.5) \mathrm{cm}$ long and $0.15 \mathrm{~cm}-0.22 \mathrm{~cm}$ wide, apex acute, base obtuse or cuneate. Presence of two stomatal bands one on each side of the midvein. Needles arranged in one plane on both sides of shoots. Sabre-shaped cryptomerioid and cupressoid shoots bearing distinctly smaller, entire-margined needles, up to $0.6 \mathrm{~cm}$ long and $0.10 \mathrm{~cm}-0.15$ $\mathrm{cm}$ wide with an acute apex and distinctly decurrent base.

Micromorphology. Features of epidermal cells of taxodioid, cryptomerioid, and cupressoid shoots similar, differing mostly in the shape and size of the stomatal bands and arrangement of the stomata.
Epidermal cells usually rectangular, between stomatal bands up to $180 \mu \mathrm{m}$ long (taxodioid) and up to $73.5 \mu \mathrm{m}$ long (cryptomerioid) and $12.3 \mu \mathrm{m}-24.5$ $\mu \mathrm{m}$ wide. Epidermal cells of the stomatal bands of all morphotypes up to $80 \mu \mathrm{m}$ long. Cell walls straight, sometimes rounded, end walls usually oblique. Cuticle thick and covered by epicuticular wax granules. Hypodermis present, poorly preserved. Taxodioid shoots with wide stomatal bands composed of several stomatal rows, longer axes of these stomata more or less parallel to the midvein of needle. Stomatal bands of cryptomerioid type arranged in narrow bands, longer axes of stomata randomly oriented to midvein. Stomata monocyclocytic, elliptic to wide elliptic, $41 \mu \mathrm{m}-66 \mu \mathrm{m}$ long and $24.0 \mu \mathrm{m}-41.7 \mu \mathrm{m}$ wide. Outer stomatal ledge aperture elliptic-oblongate (sausage-like), $17.0 \mu \mathrm{m}-$ $39.2 \mu \mathrm{m}$ long (taxodioid) and $14.7 \mu \mathrm{m}-17.1 \mu \mathrm{m}$ long (cryptomerioid) and $7.3 \mu \mathrm{m}-14.7 \mu \mathrm{m}$ wide. Polar T-shaped cuticular thickening always present, distinct.

\section{Specimens Examined}

KRAM-P 225: 40/III, 44/VI, 70/II, 86/VII, 91/IV, 92/ III, 93/VI, 96/III, 105/IV, 108, 110/III, 115, 116, 120/ III.

\section{Remarks}

The discussed remains of the conifer are macromorphologically most similar to fossil Sequoia abietina (Brongniart) Knobloch. However, Taxodium dubium (Sternberg) Heer also displays a similar macromorphology. Nevertheless, shoots of Taxodium dubium have shorter and narrower needles and the orientation of the longer axes of stomata is perpendicular or slightly oblique to the 
longer axis of a needle in Taxodium, whereas in taxodioid shoots of Sequoia abietina the longer axes of stomata are parallel to the needle axis, similar to the above described remains from Bełchatów. Sequoia abietina typically displays polymorphous shoots: taxodioid, cryptomerioid, and cupressoid (Dyjor et al., 1992).

\section{Modern Equivalents}

The fossil Sequoia abietina is comparable to recent Sequoia sempervirens (D. Don) Endl. from western North America (Knobloch, 1969). This species grows on the slopes of the Coastal Range Mountains, mainly in California (Roy, 1966; Watson, 1993).

\section{Ecology}

The taxon is considered as a riparian element (Kovar-Eder et al., 2001) or as a tree typical of the raised bog stage of the succession of the coalforming vegetation (Schneider, 1992). Extant Sequoia sempervirens from California grows in a warm-summer mediterranean climate (Csb type in the Köppen-Geiger climate classification, Kottek et al., 2006), usually in moist places where summer fogs occur (Roy, 1966).

\section{Occurrences}

Sequoia abietina commonly occurs in Neogene plant assemblages of Central Europe (Dyjor et al., 1992). In Poland it is found from the early to late Miocene (Worobiec et al., 2008).

Clade ANGIOSPERMAE Lindley, 1830

Family CERCIDIPHYLLACEAE Engler, 1907 Genus CERCIDIPHYLLUM Siebold and Zuccarini, 1846

Type Species. Cercidiphyllum japonicum Siebold and Zuccarini ex J. J. Hoffmann and J. H. Schultes, 1852

\section{cf. Cercidiphyllum crenatum (Unger) R. W. Brown emend. Z. Kvaček and Konzalová, 1996}

Figure 4.2

\section{Description}

Macromorphology. Leaf fragment ca. $5 \mathrm{~cm}$, base cordate. Margin crenate, veins terminating in sinus between teeth. Venation palmate: actinodromous, perfect, basal. Primary vein branched into nine branches. Tertiary venation weakly percurrent.

\section{Specimens Examined}

KRAM-P 225: 44/II.

\section{Remarks}

Crenate margin and palmate venation are consistent with fossil Cercidiphyllum crenatum (Unger) R.W. Brown emend. Z. Kvaček and Konzalová. However, due to the poor state of preservation, taxonomical determination is only provisional.

\section{Modern Equivalents}

Probably extant $C$. japonicum, growing in Japan and China in moist valley mountainous forests (Kvaček and Konzalová, 1996; Wei et al., 2010), the only extant relative of $C$. crenatum.

\section{Ecology}

Cercidiphyllum crenatum is considered to be a component of the Neogene wetland vegetation (Kvaček and Konzalová, 1996; Kovar-Eder et al., 1998).

\section{Occurrence}

Cercidiphyllum crenatum is found in the Neogene deposits in Europe, Asia, and North America. In Poland it is rarely found in Miocene assemblages (Worobiec et al., 2008).

Family MYRICACEAE Richard ex Kunth, 1817, in Bonpland et al. (1817)

Genus MYRICA Linnaeus, 1753

Type Species. Myrica gale Linnaeus, 1753

Myrica lignitum (Unger) Saporta, 1865

Figure 5.1-8

\section{Description}

Macromorphology. Usually fragmentary, elongated leaves, up to $9 \mathrm{~cm}$ long and $1.2 \mathrm{~cm}-2.4 \mathrm{~cm}$ wide. Leaf apex acute to attenuate, leaf base cuneate to decurrent. Presence of both entire-margined and simple serrate leaves. Apical and basal sides of teeth usually acuminate. Teeth apex acute. Secondary veins terminating at the teeth apex. Petiole up to $1.0 \mathrm{~cm}$ long. Venation pinnate. Primary vein straight, stout. Secondary venation brochidodromous. Numerous thin secondary veins runing off primary vein at intervals of $0.4 \mathrm{~cm}-0.8$ $\mathrm{cm}$ and forming an angle of $60^{\circ}-90^{\circ}$ with it. Secondaries curved upwards and near the leaf margin, interconnected in loops. Intersecondary veins present, distinct. Tertiary venation composite intersecondary to random reticulate. Higher-order venation random reticulate. Areoles well developed, 0.42 $\mathrm{mm}-1.20 \mathrm{~mm}$ in size. Veinlets always multiple branched. Numerous glandular trichome shields often attached to the surfaces of leaf impressions. 

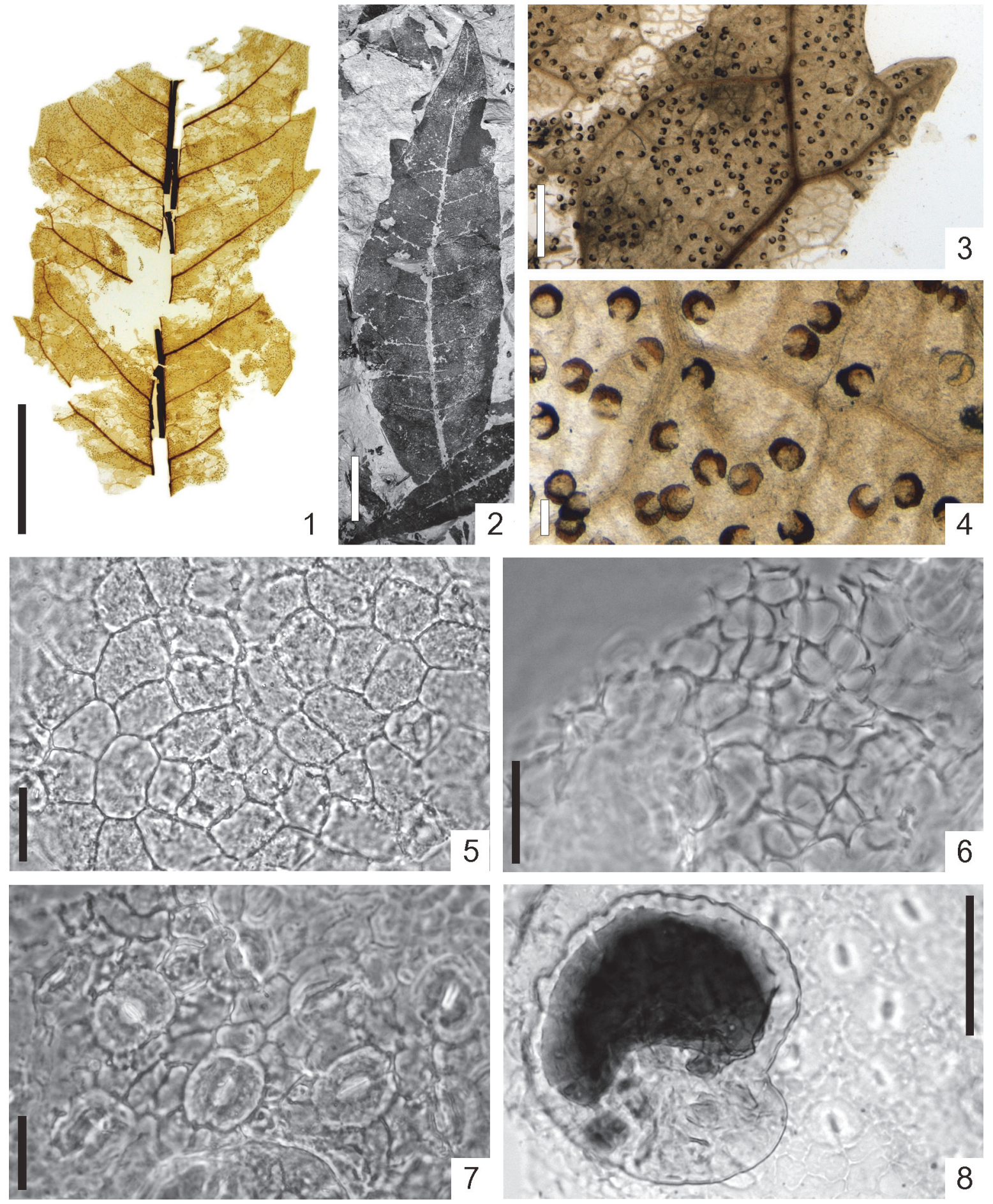

FIGURE 5. Myrica lignitum (Unger) Saporta: 1. Leaf fragment, KRAM-P 225/35; 2. Nearly whole leaf, KRAM-P 225/ 119/III; 3. Detail of tooth, KRAM-P 225/35; 4. Glandular trichome shields on leaf epidermis, KRAM-P 225/35; 5. Adaxial epidermis, KRAM-P 225/33; 6. hypodermis below adaxial epidermis, KRAM-P 225/34; 7. Abaxial epidermis with stomata, KRAM-P 225/35; 8. Glandular peltate trichome with remains of resinous secretion, KRAM-P 225/35. Scale bar equals to $1 \mathrm{~cm}$ for (1) and (2), $1 \mathrm{~mm}$ for (3), $100 \mu \mathrm{m}$ for (4), $50 \mu \mathrm{m}$ for (8), and $20 \mu \mathrm{m}$ for (5), (6), and (7). 
Micromorphology. Adaxial epidermis composed of more or less isodiametric cells, $12.3 \mu \mathrm{m}-27.0$ $\mu \mathrm{m}$ in size. Anticlinal cell walls straight to rounded. Cuticle covered by epicuticular wax. Presence of hypodermis below adaxial epidermis, composed of roundish cells, $7.3 \mu \mathrm{m}-12.3 \mu \mathrm{m}$. Abaxial epidermis consisting of irregular-shaped, isodiametric to elongated cells, $12.3 \mu \mathrm{m}-19.6 \mu \mathrm{m}$ in size. Anticlinal cell walls rounded. Cuticle covered by epicuticular wax. Leaves hypostomatic. Stomata anomocytic, rounded or widely elliptic, $20 \mu \mathrm{m}-25 \mu \mathrm{m}$ in diameter. Outer stomatal ledge aperture wide elliptic or rounded, $7.3 \mu \mathrm{m}-12.3 \mu \mathrm{m}$ in size. Polar T-shaped cuticular thickening visible on undermacerated cuticular fragments. On the abaxial epidermis, presence of numerous glandular peltate trichomes. Trichome shield multicellular, composed of radiately arranged cells, $86 \mu \mathrm{m}-118 \mu \mathrm{m}$ in diameter. Remains of resinous secretion preserved inside some trichomes. Two-celled trichome bases, irregularly-elliptic, $20 \mu \mathrm{m}-25 \mu \mathrm{m}$ in size.

\section{Specimens Examined}

KRAM-P 225: 33, 34, 35, 40/II, 41/II, 43/II, 44/IV, 47/IV, 49/II, 54/II, 55/II, 58/V, 60/VI, 63/II, 68/IV, 69/ II, 71/III, 72/IV, 74/II, 77/II, 80, 81/II, 82/II, 83/IV, 85/ II, 86/V, 87/II, 88/N, 90, 91/III, 93/III, 94/II, 95/II, 96/ II, 97/II, 99/I, 104/IV, 105/III, 106/II, 110/II, 119/III, 129, 130, 131.

\section{Remarks}

The described leaves are macro- and micromorphologically similar to Myrica lignitum (Unger) Saporta sensu lato. The shape of both entire-margined and serrate leaves, venation pattern, and epidermal structure (stomata, peltate glandular trichomes) are typical for this fossil species. The fossil leaves of Myrica are macromorphologically very similar to fossil leaves of the genus Engelhardia Lesch. ex Bl. from the Juglandaceae family. Engelhardia differs from Myrica in the asymmetrical shape of the leaflets, which are usually smaller than Myrica leaves, and in the one-celled bases of glandular trichomes.

\section{Modern Equivalents}

Macromorphologically Myrica lignitum resembles several extant species of the same genus from North America, East Asia, and tropical mountain forests of Africa (llinskaya, 1964; Knobloch, 1969).

\section{Ecology}

Usually considered as a component of acid, swampy communities (Zidianakis et al., 2015).

\section{Occurrence}

Myrica lignitum is a common element of Neogene fossil floras (Knobloch and Kvaček, 1976).

$$
\text { Family BETULACEAE Gray, } 1821
$$

Genus ALNUS Miller, 1754

Type Species. Alnus glutinosa (Linnaeus) J. Gærtner, 1791 .

$$
\begin{gathered}
\text { Alnus ducalis (Gaudin) Knobloch, } 1969 \\
\text { Figure 6.1-4 }
\end{gathered}
$$

\section{Description}

Macromorphology. Leaves up to $6.5 \mathrm{~cm}$ long and $5.2 \mathrm{~cm}$ wide. Leaf apex strongly emarginate, leaf base obtuse and slightly decurrent, mostly without teeth. Leaf margin serrate, teeth large, apical and basal sides of teeth acuminate. Teeth apex acute. Secondary veins and subsidiary veins terminating at the teeth apex. Venation pinnate, primary vein straight, of moderate thickness. Secondary venation simple craspedodromous, preserving up to seven pairs of secondaries, veins curved upwards, distributed at intervals of $0.3 \mathrm{~cm}$ near leaf base to $0.6 \mathrm{~cm}-0.9 \mathrm{~cm}$ in the middle of the lamina. Secondary veins diverging from midvein at an angle of $60^{\circ}-80^{\circ}$ near leaf base, $45^{\circ}-60^{\circ}$ in the middle of the lamina, and decreasing to $30^{\circ}$ near leaf apex. Tertiary venation percurrent, ca. 5-8 tertiary veins occuring per $1 \mathrm{~cm}$ of secondary vein length. Tertiary venation with the primary vein forming an angle of $145^{\circ}$ near leaf base, $125^{\circ}$ in the middle of the lamina, and $100^{\circ}-115^{\circ}$ near leaf apex. Higherorder venation often orthogonal reticulate. Areoles well developed, ca. $0.4 \mathrm{~mm}$ in size.

Micromorphology. Adaxial epidermis composed of isodiametric to slightly elongate cells, $19 \mu \mathrm{m}-39 \mu \mathrm{m}$ in size. Anticlinal cell walls mainly straight. Adaxial cuticle covered by rather distinct epicuticular wax layer, sometimes cuticle also with striate ornamentation. Abaxial epidermis cells usually slightly elongated, $19.6 \mu \mathrm{m}-31.9 \mu \mathrm{m}$ in size, anticlinal cell walls usually straight, rarely rounded. Leaves hypostomatic. Stomata rather poorly preserved. Outer stomatal ledge aperture wide elliptic or spindle-shaped, ca.15 $\mu \mathrm{m}$ long and $5.0 \mu \mathrm{m}-7.3 \mu \mathrm{m}$ wide. On the abaxial epidermis, 4-celled (very rarely 5-6 celled) roundish trichome bases, $22.0 \mu \mathrm{m}-29.4$ $\mu \mathrm{m}$ in size. 

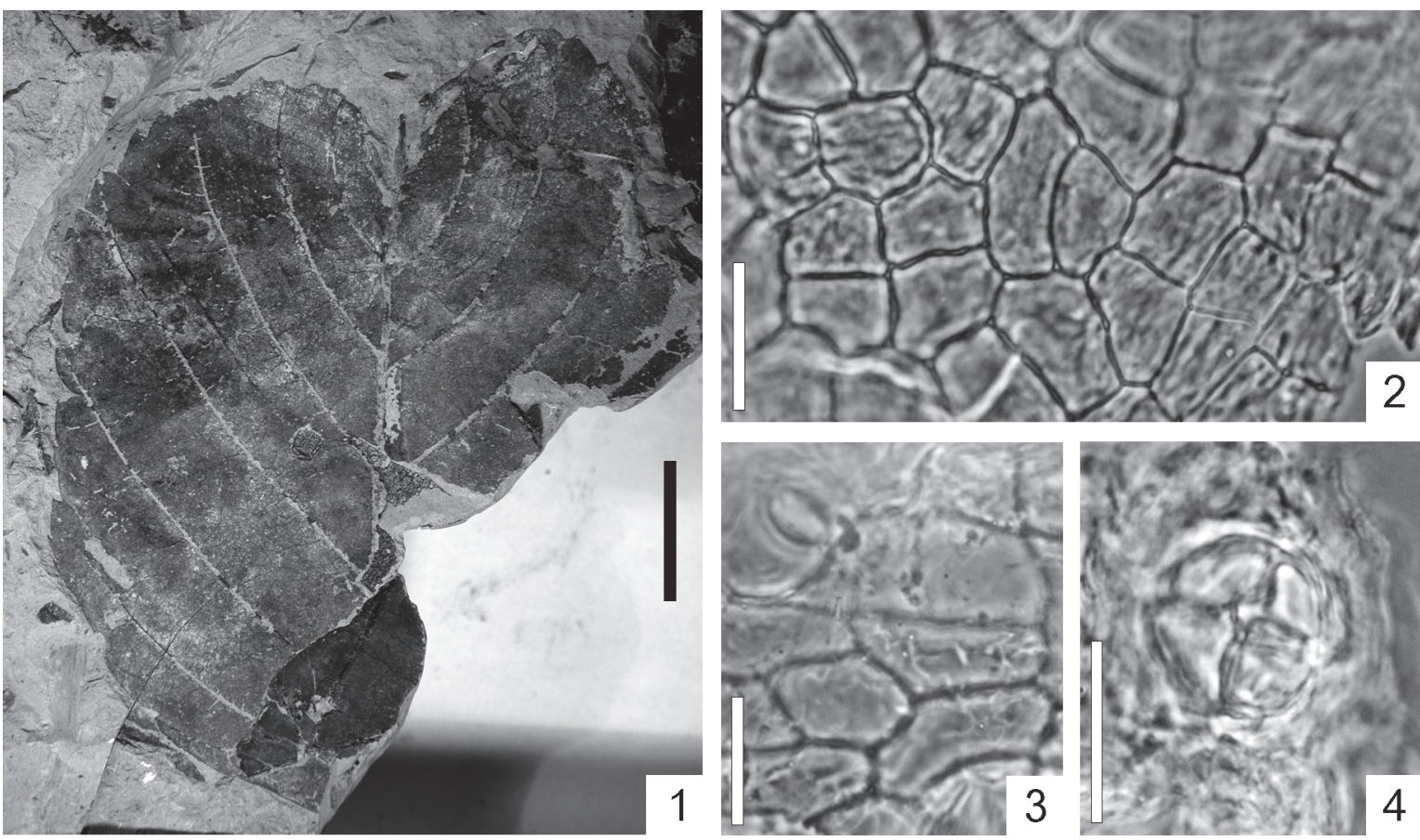

FIGURE 6. Alnus ducalis (Gaudin) Knobloch: 1. Leaf fragment, KRAM-P 225/88/l; 2. Adaxial epidermis, KRAM-P 225/ 122/I; 3. Abaxial epidermis with stoma, KRAM-P 225/88/l; 4. Four-celled base of glandular trichome, KRAM-P 225/ $122 / \mathrm{l}$. Scale bar equals to $1 \mathrm{~cm}$ for (1), and $20 \mu \mathrm{m}$ for (2), (3), and (4).

\section{Specimens Examined}

KRAM-P 225: 88/I, 122/l.

\section{Remarks}

The unique shape of this leaf type with strongly emarginate apex along with venation network unambiguously point to the fossil alder species Alnus ducalis (Gaudin) Knobloch.

\section{Modern Equivalents}

Extant Alnus matsumurae Callier from Japanese montane forests displays an almost identical morphology of leaves, especially emarginate apex (Kovar-Eder et al., 1996).

\section{Ecology}

Temperate element. Hably and Kovar-Eder (1996) and Kovar-Eder et al. (1996) considered it to be a component of riparian plant assemblages.

\section{Occurrence}

Alnus ducalis is an element of middle to late Miocene plant assemblages (Kovar-Eder et al., 1996). In Poland Al. ducalis, was previously reported only from middle Miocene localities, namely Czernica, Kokoszyce, and Młyny (KovarEder et al., 1996). Stuchlik et al. (1990) mistakenly reported a leaf fragment of Carya from Bełchatów as being Alnus ducalis (Worobiec and Szynkiewicz, 2007).

Genus BETULA Linnaeus, 1753

Type Species. Betula alba Linnaeus, 1753

Betula cf. plioplatyptera Hummel, 1991

Figure 7.1

\section{Description}

Macromorphology. Leaf fragments, up to $6 \mathrm{~cm}$ long and $1.8 \mathrm{~cm}-4.6 \mathrm{~cm}$ wide. Leaf apex probably acute, leaf base obtuse, mostly without teeth. Leaf margin double serrate, apical and basal sides of teeth more or less acuminate. Teeth apex acute. Secondary veins and subsidiary veins terminating at the teeth apex. Venation pinnate, primary vein straight, of moderate thickness. Secondary venation simple craspedodromous, preserving up to eight pairs of secondaries, veins first straight then curving upwards near leaf margin, distributed at intervals of $0.3 \mathrm{~cm}-0.4 \mathrm{~cm}$ near leaf base to 0.4 $\mathrm{cm}-0.5 \mathrm{~cm}$ in the middle of the lamina. Secondary veins diverging from midvein at an angle of $60^{\circ}-$ $70^{\circ}$ near leaf base to $40^{\circ}-55^{\circ}$ in the middle of the lamina. Tertiary venation percurrent, ca. eight tertiary veins occur per $1 \mathrm{~cm}$ of secondary vein length. Tertiary venation forming an angle of ca. $140^{\circ}$ with the primary vein. Higher-order venation 

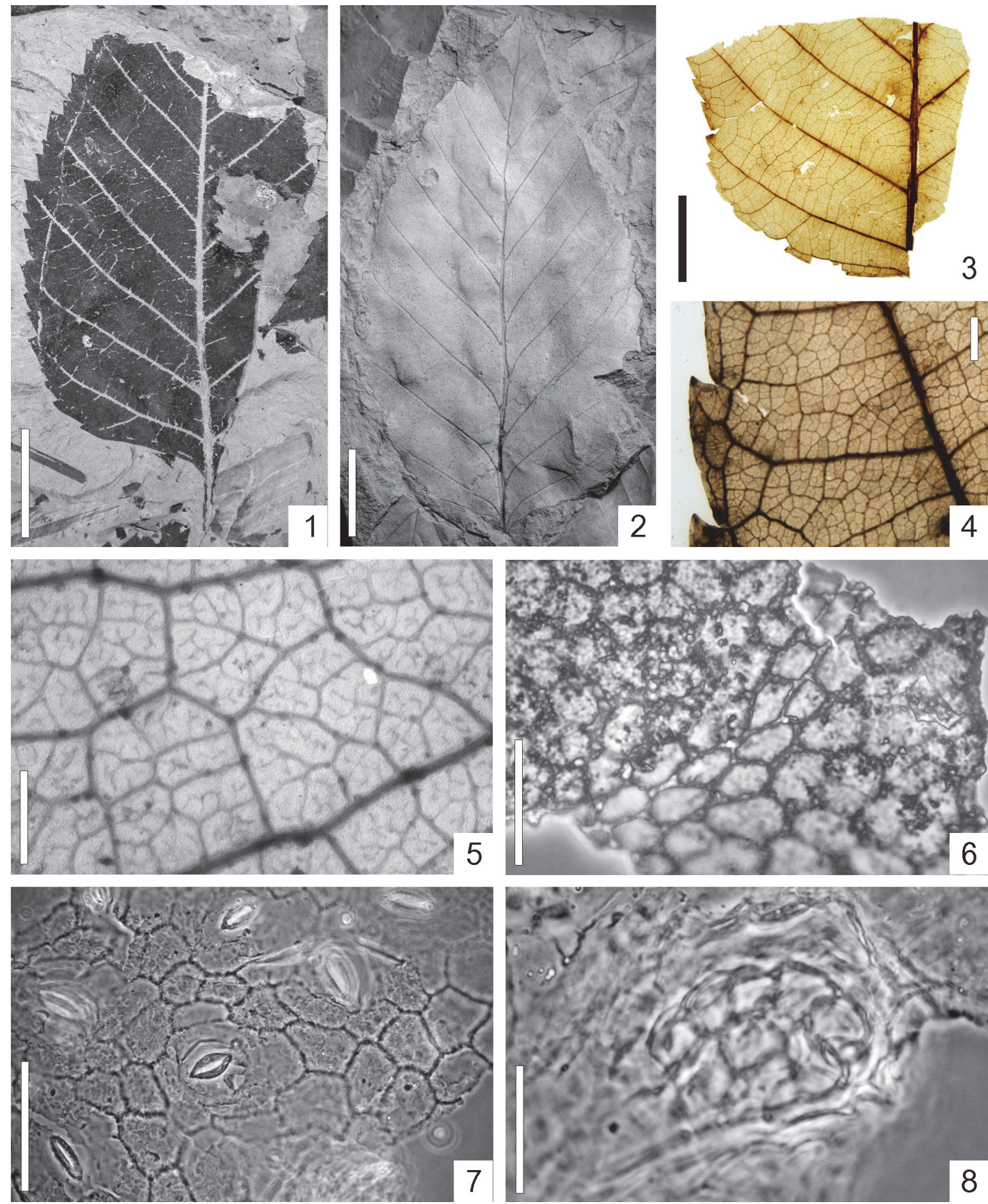

FIGURE 7. Betula cf. plioplatyptera Hummel: 1. leaf, KRAM-P 225/106/l. Betula subpubescens Goeppert emend. Worobiec: 2. leaf, KRAM-P 225/104/I; 3. Fragment of basal part of leaf, KRAM-P 225/26; 4. Detail of leaf margin and teeth venation, KRAM-P 225/26; 5. Detail of leaf areolation, KRAM-P 225/26; 6. Adaxial epidermis, KRAM-P 225/26; 7. Abaxial epidermis with stomata, KRAM-P 225/26; 8. Multicellular glandular trichome base, KRAM-P 225/27. Scale bar equals to $1 \mathrm{~cm}$ for (1), (2), and (3), $1 \mathrm{~mm}$ for (4), $0.5 \mathrm{~mm}$ for (5), $50 \mu \mathrm{m}$ for (6) and (7), and $20 \mu \mathrm{m}$ for (8). 
reticulate. Areoles well developed, $0.4 \mathrm{~mm}-0.6 \mathrm{~mm}$ in size. Veinlets multiple branched. Numerous glandular trichome shields often attached to the surfaces of leaf impressions exclusively on the impressions of leaf veins.

\section{Specimens Examined}

KRAM-P 225: 73, 93/I, 94/I, 106/l.

\section{Remarks}

The macromorphological features of the above described leaf fragments (e.g., shape of the leaves, large primary teeth) are most similar to Betula plioplatyptera Hummel. However, the diagnostic features of the latter fossil species given by Hummel (1991) do not clearly separate it from Betula subpubescens Goeppert emend. Worobiec. Thus, it should not be overlooked that Betula plioplatyptera could in fact be conspecific with Betula subpubescens and that the differences between these two fossil species could result from the natural morphological variability of their leaves.

\section{Modern Equivalents}

Betula plioplatyptera resembles the extant North American species B. papyrifera Marsh. However, it differs considerably in respect of the structure of epidermis (Hummel, 1991).

\section{Ecology}

Similarly to extant Betula papyrifera, fossil Betula plioplatyptera is considered as a temperate element.

\section{Occurrence}

In Poland the taxon is found in the Miocene deposits of Bełchatów (Worobiec and Szynkiewicz, 2007) and the early Pliocene of Ruszów (Hummel, 1991).

Betula subpubescens Goeppert emend.
Worobiec, 2007

Figure 7.2-8

\section{Description}

Macromorphology. Leaves elliptic to ovate, up to $6.2 \mathrm{~cm}$ long and $2.5 \mathrm{~cm}-4.0 \mathrm{~cm}$ wide. Leaf apex acute to attenuate, base obtuse, rounded, rarely cuneate. Petiole (rarely entirely preserved) up to $0.9 \mathrm{~cm}$ long. Leaf margin double serrate, leaf base often entire-margined. Apical and basal sides of teeth mostly acuminate, teeth apex acute. Secondary veins and subsidiary veins terminating at teeth apex. Venation pinnate, primary vein straight, of moderate thickness. Secondary venation simple craspedodromous, up to 9-11 pairs of secondaries preserved, arising at intervals of $0.4 \mathrm{~cm}-0.5 \mathrm{~cm}$ near leaf base and $0.4 \mathrm{~cm}-1.0 \mathrm{~cm}$ in the middle of the lamina. Secondaries more or less straight or curved upwards near leaf margin, diverging from midvein at an angle of $60^{\circ}-70^{\circ}$ near leaf base and $40^{\circ}-55^{\circ}$ in the middle of the lamina. Tertiary venation percurrent, convex, 5-10 tertiary veins occurring per $1 \mathrm{~cm}$ of secondary vein length and forming an angle of ca. $140^{\circ}$ with the primary vein. Higherorder venation reticulate. Areoles well developed, $0.3 \mathrm{~mm}-0.6 \mathrm{~mm}$ in size. Veinlets multiple branched. Marginal ultimate venation incompletely looped. On some leaf impressions, presence of glandular trichome shields attached to the specimen surfaces exclusively on the impressions of leaf veins.

Micromorphology. Adaxial epidermis composed of more or less isodiametric cells, $15.0 \mu \mathrm{m}-29.6$ $\mu \mathrm{m}$ in size with usually straight, rarely rounded, anticlinal cell walls. Adaxial cuticle covered by a distinct epicuticular wax layer. Abaxial epidermis composed of isodiametric to elongated cells, $12.3 \mu \mathrm{m}-$ $36.8 \mu \mathrm{m}$ in size, over the veins strongly elongated with straight to rounded anticlinal cell walls. Abaxial cuticle also covered by an indistinct epicuticular wax layer. Leaves hypostomatic. Stomata anomocytic, elliptic to narrow elliptic, $19.6 \mu \mathrm{m}-34.3 \mu \mathrm{m}$ long and $12.3 \mu \mathrm{m}-19.6 \mu \mathrm{m}$ wide. Outer stomatal ledge aperture wide elliptic or rounded, $14.7 \mu \mathrm{m}-22.0 \mu \mathrm{m}$ long and $4.9 \mu \mathrm{m}-9.8 \mu \mathrm{m}$ wide. Presence of glandular peltate trichomes on the abaxial epidermis. Trichome shield ca. $74 \mu \mathrm{m}$ in diameter. On the abaxial epidermis, presence of glandular trichome bases, multicellular (5- to 10-celled, very rarely 4-celled), $27.0 \mu \mathrm{m}-36.7 \mu \mathrm{m}$ in size.

\section{Specimens Examined}

KRAM-P 225: 26, 28, 39/I, 42/I, 47/I, 60/I, 64/III, 66/I, 67/I, 68/I, 71/I, 72/I, 74/I, 88/II, 89/I, 91/I, 95/I, 104/I, 117, 125/I, 126, 128. cf. Betula subpubescens: 27.

\section{Modern Equivalents}

Betula subpubescens is comparable to recent Betula pubescens Ehrh., B. utilis D. Don., B. davurica Pall. (Hummel, 1991), and to B. verrucosa Ehrh. (Němejc, 1949).

\section{Ecology}

Similarly to modern equivalents, fossil Betula subpubescens is considered as a temperate element. 


\section{Occurrence}

In Poland the species is found in middle Miocene to lower Pliocene deposits (Krajewska, 1998).

Betula sp.

\section{Description}

Badly preserved fragments of leaves of Betula.

\section{Specimens Examined}

KRAM-P 225: 44/I, 83/I, 86/I, 105/I, 123/l.

\section{Remarks}

These remains of leaves of fossil birch are so badly preserved that a precise identification is not possible. One scale of birch catkin was also found (specimen KRAM-P 225/125/II).

Genus CARPINUS Linnaeus, 1753

Type Species. Carpinus betulus Linnaeus, 1753.

Carpinus grandis Unger emend. Heer, 1856

Figure 8.1-4, 8.6-7

\section{Description}

Macromorphology. Leaves usually ovate, up to $5.7 \mathrm{~cm}$ long and $1.8 \mathrm{~cm}-3.0 \mathrm{~cm}$ wide with attenuate apex and obtuse, rounded, or slightly cordate base. Leaf margin double serrate, teeth small, numerous (especially in basal part of leaf), more or less of the same size, apical side of teeth acuminate (rarely concave), basal side acuminate (rarely convex). Teeth apex sharply acute, teeth often hook-shaped towards leaf apex. Secondary veins and their branches terminating at the teeth apex. Venation pinnate, primary vein straight, of moderate thickness or thin. Secondary venation simple craspedodromous. Secondaries preserved in up to 13 pairs, more or less straight or curved upwards near leaf margin, distributed at intervals of ca. 0.3 $\mathrm{cm}$ near leaf base and $0.4 \mathrm{~cm}-0.6 \mathrm{~cm}$ in the middle part of the lamina. Secondary veins diverging from midvein at an angle of $60^{\circ}-70^{\circ}$ near leaf base and $40^{\circ}-55^{\circ}$ in the middle of the lamina, usually producing numerous branches entering the nearest teeth close to the leaf margin. Tertiary venation percurrent, forming an angle of $120^{\circ}-125^{\circ}$ with the primary vein. Ten to 12 (sometimes 14) tertiary veins occurring per $1 \mathrm{~cm}$ of secondary vein length. Higher-order venation predominately orthogonal reticulate. Areoles well developed, $0.36 \mathrm{~mm}-0.60$ $\mathrm{mm}$ in size. Veinlets simple or absent. Marginal ultimate venation incompletely looped.
Micromorphology. Adaxial epidermis composed of isodiametric or slightly elongated cells $12.3 \mu \mathrm{m}-$ $29.4 \mu \mathrm{m}$ in size, with straight, rounded, or sometimes slightly undulate anticlinal cell walls. Adaxial cuticle covered by a distinct epicuticular wax layer. Walls of abaxial epidermis cells mostly not visible, straight to rounded, ca. $30 \mu \mathrm{m}$ in size. Leaves hypostomatic. Stomata roundish, $14.7 \mu \mathrm{m}-19.6 \mu \mathrm{m}$ in diameter. Outer stomatal ledge aperture elliptic, narrow elliptic, sometimes spindle-shaped, $6.1 \mu \mathrm{m}-$ $9.8 \mu \mathrm{m}$ long and $3.7 \mu \mathrm{m}-4.9 \mu \mathrm{m}$ wide. Trichomes not found.

\section{Specimens Examined}

KRAM-P 225: 29, 30, 31, 32, 39/II, 40/IV, 41/I, 47/ II, 58/I, 60/II, 64/I, 70/I, 71/II, 72/II, 75/I, 76, 77/I, 79/I, 83/II, 86/II, 88/III, 93/II, 96/I, 98, 102, 104/II, 105/II, 107/I, 120/I, 122/II, 123/II, 125/III, 132.

\section{Remarks}

Double serrate leaf margin with considerably small teeth, secondary veins branching, and venation of the leaf base are characteristics of the fossil species Carpinus grandis Unger emend. Heer. This is probably a collective species (Mai and Walther, 1978, 1988; Hummel, 1991; Zastawniak and Walther, 1998).

\section{Modern Equivalents}

Carpinus grandis corresponds to recent hornbeam species of section Eucarpinus (comp. Krüssmann, 1976) and could be compared to Carpinus betulus L. (Heer, 1856; Zastawniak, 1972; Hummel, 1991; Krajewska, 1998), Carp. caucasica Grossh. (Hummel, 1991), and Carp. orientalis Mill. (llinskaya, 1968).

\section{Ecology}

Similarly to modern equivalents, fossil Carpinus grandis is considered as a temperate element.

\section{Occurrence}

Carpinus grandis is known from the middle Oligocene to the late Pliocene plant assemblages from Europe (Mai and Walther, 1978, 1988; Hummel, 1991: Zastawniak and Walther, 1998). In Poland this fossil taxon can be found from the early Miocene to the early Pliocene (Hummel, 1991; Krajewska, 1998; Worobiec et al., 2008).

\section{Carpinus sp. \\ Figure 8.5}

\section{Description}

Badly preserved fragments of fruit involucre. 

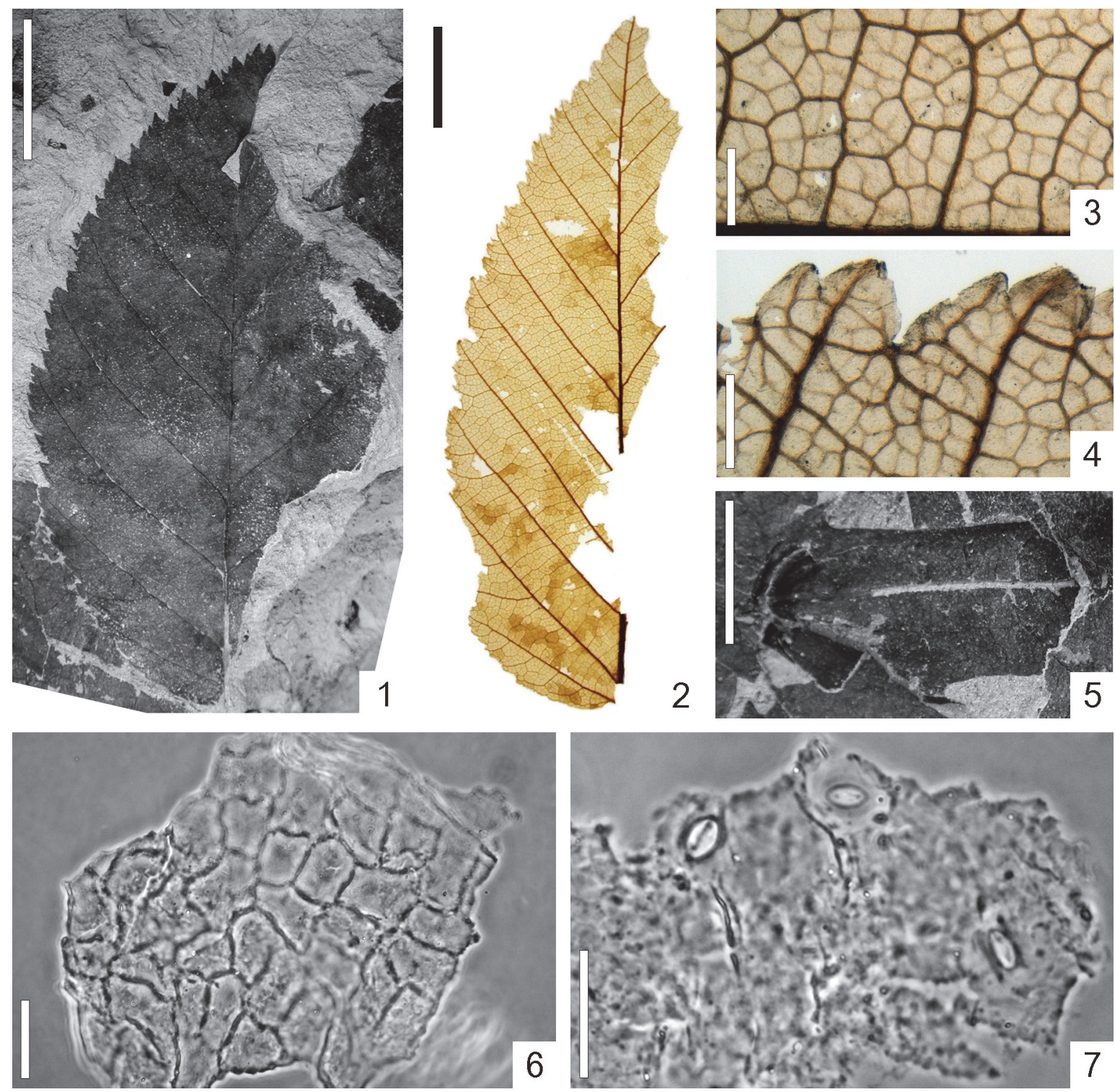

FIGURE 8. Carpinus grandis Unger emend. Heer: 1. Leaf, KRAM-P 225/40/IV; 2. Leaf, KRAM-P 225/30; 3. Detail of leaf areolation, KRAM-P 225/30; 4. Detail of leaf margin and teeth venation, KRAM-P 225/30; 6. Adaxial epidermis, KRAM-P 225/31; 7. Abaxial epidermis with stomata, KRAM-P 225/31. Carpinus sp.: 5. Fragment of fruit involucre, KRAM-P 225/91/ll. Scale bar equals to $1 \mathrm{~cm}$ for (1), $0.5 \mathrm{~cm}$ for (2) and (5), $0.5 \mathrm{~mm}$ for (3) and (4), and $20 \mu \mathrm{m}$ for (6) and (7).

\section{Specimens Examined}

KRAM-P 225: 91/II, 119/I.

\section{Remarks}

Remains of fruits of fossil hornbeam. Due to the poor state of preservation, a more precise identification is not possible.

BETULACEAE indet.

\section{Specimens Examined}

KRAM-P 225: 41/III, 45/II, 49/III, 51/III, 52/II, 55/III, 60/VIII, 67/IV, 68/I, 69/III, 72/N, 78/II, 82/III, 91/N, $101,105 / \mathrm{V}$.

\section{Remarks}

On the basis of the serration of leaf margin typical of Betulaceae members, these leaf fragments undoubtedly belong to the Betulaceae family. Due to the rather poor state of preservation, a more precise identification is not possible. 
Family FAGACEAE Dumortier, 1829

Genus FAGUS Linnaeus, 1753

Type Species. Fagus sylvatica Linnaeus, 1753.

Fagus silesiaca Walther and Zastawniak, 1991 Figure 9.1-6

\section{Description}

Macromorphology. Leaves elliptic, up to $6.8 \mathrm{~cm}$ long and $3.0 \mathrm{~cm}-3.5 \mathrm{~cm}$ wide. Leaf apex attenuate, leaf base obtuse. Leaf margin simple serrate, teeth upwardly curved, apical side of teeth concave, basal side acuminate or straight, teeth apex rounded. Venation pinnate, primary vein thin, sometimes sinuous (zig-zag). Secondary venation simple craspedodromous. Secondaries alternate, preserved in up to ten pairs, straight, right on leaf margin sometimes upwardly curved, distributed at intervals of $0.5 \mathrm{~cm}-$ $0.9 \mathrm{~cm}$. Secondary veins diverging from midvein at an angle of $40^{\circ}-50^{\circ}$. Tertiary venation percurrent, forming an angle of $125^{\circ}-135^{\circ}$ with the primary vein. Eight to 10 tertiary veins occurring per $1 \mathrm{~cm}$ of secondary vein length. Four-order venation orthogonal reticulate. Areoles well developed, $0.36 \mathrm{~mm}-$ $0.48 \mathrm{~mm}$ in size. Veinlets simple or absent. Marginal ultimate venation looped.

Micromorphology. Adaxial epidermis composed of usually slightly elongated cells with undulate cell walls (sometimes straight-walled), $25.0 \mu \mathrm{m}-41.7 \mu \mathrm{m}$ in size. Over veins cells straight-walled. Abaxial epidermis consisting of variable-shaped cells with straight (rarely rounded) cell walls, $19.6 \mu \mathrm{m}-36.8 \mu \mathrm{m}$ in size. Leaves hypostomatic. Stomata cyclocytic, roundish, sometimes wide elliptic, $20 \mu \mathrm{m}-25 \mu \mathrm{m}$ in diameter. T-shaped cuticular thickenings usually slightly visible at poles of guard cells. Outer stomatal ledge elliptic, $9.8 \mu \mathrm{m}-12.3 \mu \mathrm{m}$ long and $4.9 \mu \mathrm{m}-7.4$ $\mu \mathrm{m}$ wide. On abaxial epidermis, presence of unicellular trichome bases, roundish, $9.8 \mu \mathrm{m}-13.5 \mu \mathrm{m}$ in diameter.

\section{Specimens Examined}

KRAM-P 225: 12, 15, 24, 67/II, 79/II, 89/II, 104/III, 121.

\section{Remarks}

The venation network, the serration of the leaf margin, and the stomatal complex are typical of leaves of the genus Fagus. The shape of the leaves and the number of secondary veins are consistent with the fossil species Fagus silesiaca Walther and Zastawniak (Walter and Zastawniak, 1991).

\section{Modern Equivalents}

In terms of macro- and micromorphology, the leaves of Fagus silesiaca are similar to the leaves of the extant Chinese beech Fagus hayatae Palibin ex Hayata (Dyjor et al., 1992). The leaves of Fagus grandiflora Ehrh. from North America, macromorphologically similar to Fagus silesiaca, differ in having anomocytic stomata (Kvaček and Walther, 1991).

\section{Ecology}

Fossil Fagus siliesaca is considered as a warm temperate element (Worobiec, 2014).

\section{Occurrence}

Fagus silesiaca is common in late Miocene to early Pliocene leaf assemblages of Central Europe (Walther, 1994). In Poland, it is reported from middle Miocene to Pliocene floras (Worobiec, 2003b).

Family JUGLANDACEAE de Candolle ex Perleb, 1818 Juglandaceae DC. ex Perleb, nom. cons. Genus CARYA Nuttal, 1818

Type Species. Carya tomentosa (Lamarck) Nuttall, 1818.

\section{Carya serrifolia (Goeppert) Kräusel, 1920}

Figure 10.1-7

\section{Description}

Macromorphology. Only fragments of leaflets, up to $8.5 \mathrm{~cm}$ long and $3.5 \mathrm{~cm}-6.5 \mathrm{~cm}$ wide, leaflet base obtuse. Leaflet margin simple serrate, apical side of teeth acuminate or concave, basal side acuminate (sometimes convex or concave), teeth apex acute, nearly spinose. Branches of secondary veins terminating at teeth apex. Venation pinnate, primary vein straight and of moderate thickness. Secondary venation mixed craspedodromous. Secondaries alternate, preserved in up to 17 pairs distributed at intervals of $0.4 \mathrm{~cm}-0.5 \mathrm{~cm}$ near leaflet base and 0.5 $\mathrm{cm}-1.3 \mathrm{~cm}$ in the middle part of the lamina, slightly upwardly curved, near the leaflet margin strongly curved and interconnected in loops sending fine veins towards teeth. Secondary veins diverging from midvein at an angle of $80^{\circ}-90^{\circ}$ near leaflet base to $55^{\circ}-80^{\circ}$ in the middle of the lamina. Tertiary venation percurrent, 4-6 tertiary veins occuring per $1 \mathrm{~cm}$ of secondary vein length and forming an angle of $130^{\circ}-160^{\circ}$ with the primary vein. Higher-order venation reticulate. Areoles well developed, $0.18 \mathrm{~mm}-0.30 \mathrm{~mm}$ in size. Veinlets simple or absent (rarely branched once). Marginal ultimate venation looped. Numerous glandular trichome 

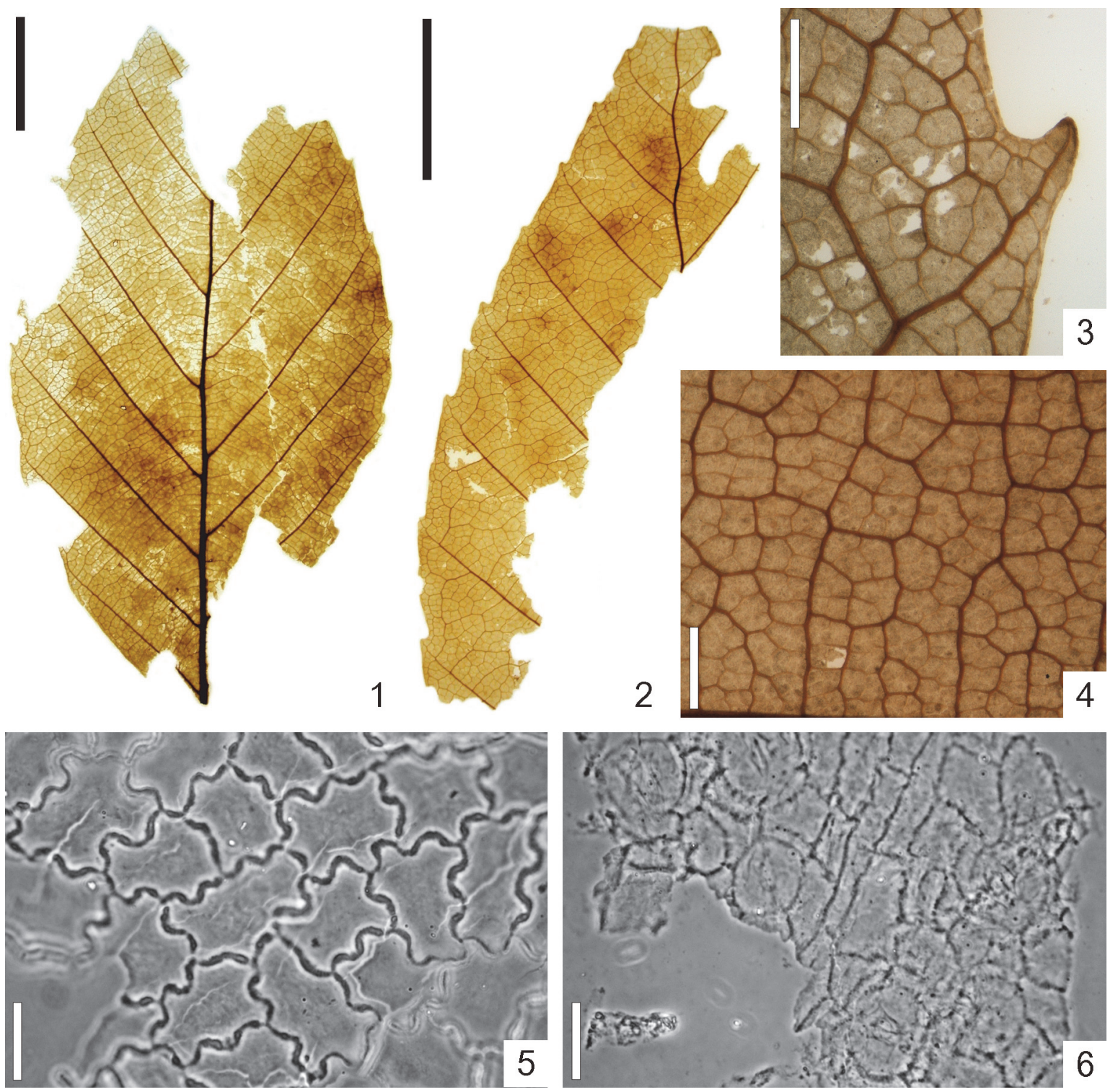

FIGURE 9. Fagus silesiaca Walther and Zastawniak: 1. Leaf fragment, KRAM-P 225/15; 2. Leaf fragment, KRAM-P 225/12; 3. Detail of leaf margin and tooth venation, KRAM-P 225/24; 4. Detail of leaf areolation, KRAM-P $225 / 24 ; 5$. Adaxial epidermis, KRAM-P 225/24; 6 . Abaxial epidermis with stomata, KRAM-P 225/12. Scale bar equals to $1 \mathrm{~cm}$ for (1) and (2), $1 \mathrm{~mm}$ for (3) and (4), and $20 \mu \mathrm{m}$ for (5) and (6).

shields often attached to the surfaces of leaflet impressions.

Micromorphology. Adaxial epidermis consisting of slightly elongated cells with straight, rounded (or more seldom, slightly undulate) cell walls, $22.0 \mu \mathrm{m}-$ $41.7 \mu \mathrm{m}$ in size. Abaxial epidermis rather badly preserved, cells isodiametric or slightly elongated, straight-walled, ca. $30 \mu \mathrm{m}$ in size. Leaflets hypostomatic. Stomata elliptic to wide elliptic, 22 $\mu \mathrm{m}-24 \mu \mathrm{m}$ in size. Indistinct T-shaped cuticular thickenings at poles of guard cells. On abaxial epidermis, presence of peltate trichome shields (scales), $134 \mu \mathrm{m}-171 \mu \mathrm{m}$ in diameter. Trichome bases unicellular (rarely two-celled), roundish to elliptic, $22 \mu \mathrm{m}-29 \mu \mathrm{m}$ in diameter.

\section{Specimens Examined}

KRAM-P 225: 2, 8, 18, 19, 78/I, 84, 88/IV, 103, 109, 111, 112, 114, 118, 120/II.

\section{Remarks}

The leaflet shape, the mixed craspedodromous venation, and the secondary veins branching point to the fossil species Carya serrifolia (Goeppert) Kräusel. Leaflets of fossil Pterocarya paradisiaca (Unger) llinskaya, somewhat similar to those of 

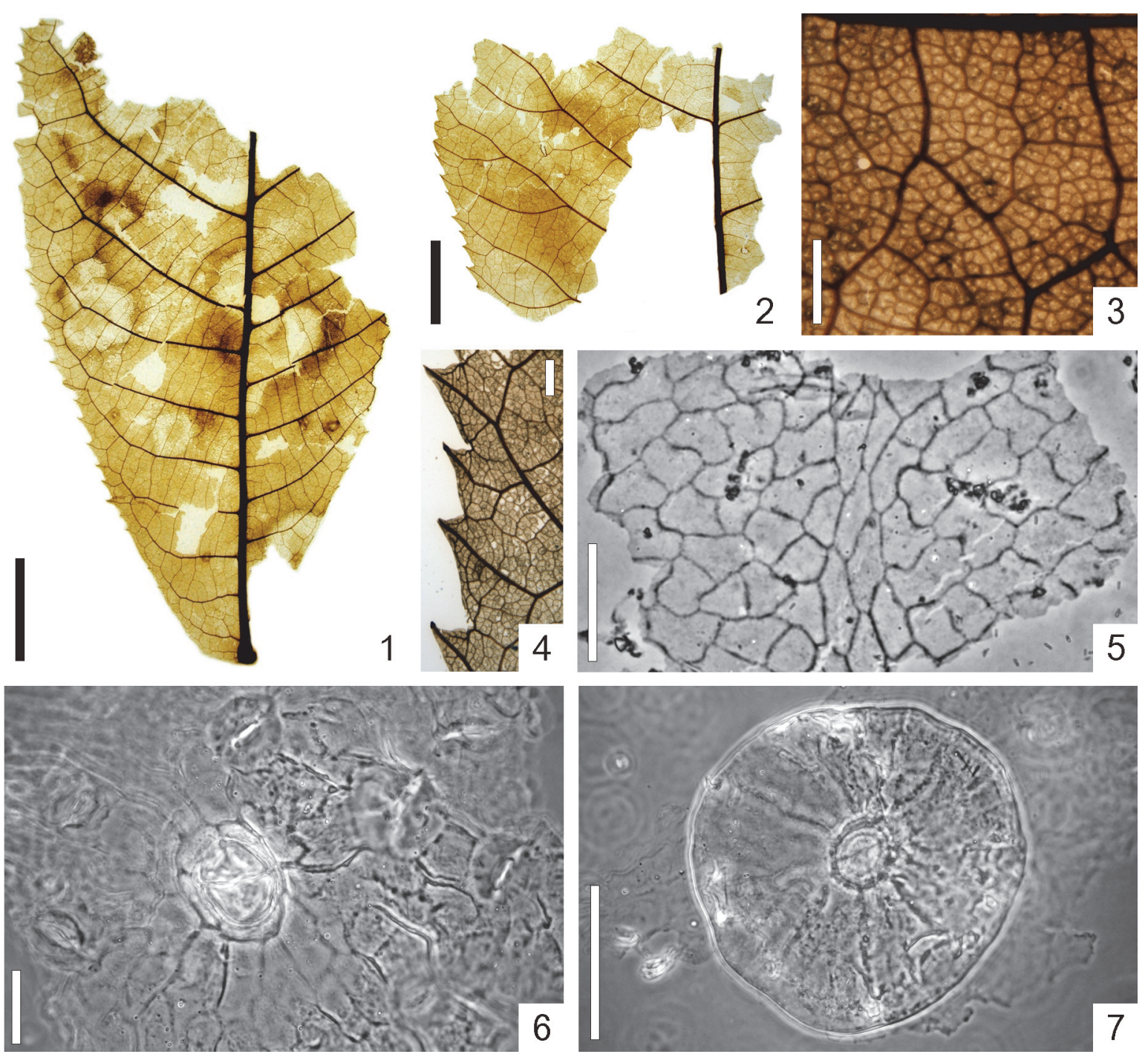

FIGURE 10. Carya serrifolia (Goeppert) Kräusel: 1. Leaflet, KRAM-P 225/18; 2. Leaflet fragment, KRAM-P 225/19; 3. Detail of leaflet areolation, KRAM-P 225/8; 4. Detail of leaflet margin and teeth venation, KRAM-P 225/19; 5. Adaxial epidermis, KRAM-P 225/8; 6. Abaxial epidermis with stomata and one-celled glandular trichome base, KRAM-P 225/ 8; 7. Glandular peltate trichome, KRAM-P 225/18. Scale bar equals to $1 \mathrm{~cm}$ for (1) and (2), $1 \mathrm{~mm}$ for (3) and (4), 50 $\mu \mathrm{m}$ for (5) and (7), and $20 \mu \mathrm{m}$ for (6).

Carya serrifolia, usually differ in displaying an oblongated shape.

\section{Modern Equivalents}

Carya serrifolia is usually compared with extant North American species Carya aquatica (F.Michx.) Nutt., Carya illinoinensis (Wangenh.) K. Koch., and Carya tomentosa Nutt. (Teodoridis, 2002).

\section{Ecology}

Fossil Carya serrifolia is considered as a warm temperate element (Hably and Kvaček, 1998).

\section{Occurrence}

Carya serrifolia is common in Neogene European fossil plant assemblages (Knobloch, 1969; Palamarev and Petkova, 1987). In Poland, this fossil species is found from the middle Miocene to the early Pliocene (Worobiec, 2003b).

Family SAPINDACEAE Jussieu, 1789

Genus ACER Linnaeus, 1753

Type Species. Acer pseudoplatanus Linnaeus, 1753.

Acer tricuspidatum Bronn sensu Procházka and Bůžek, 1975

Figure 11.1-4 

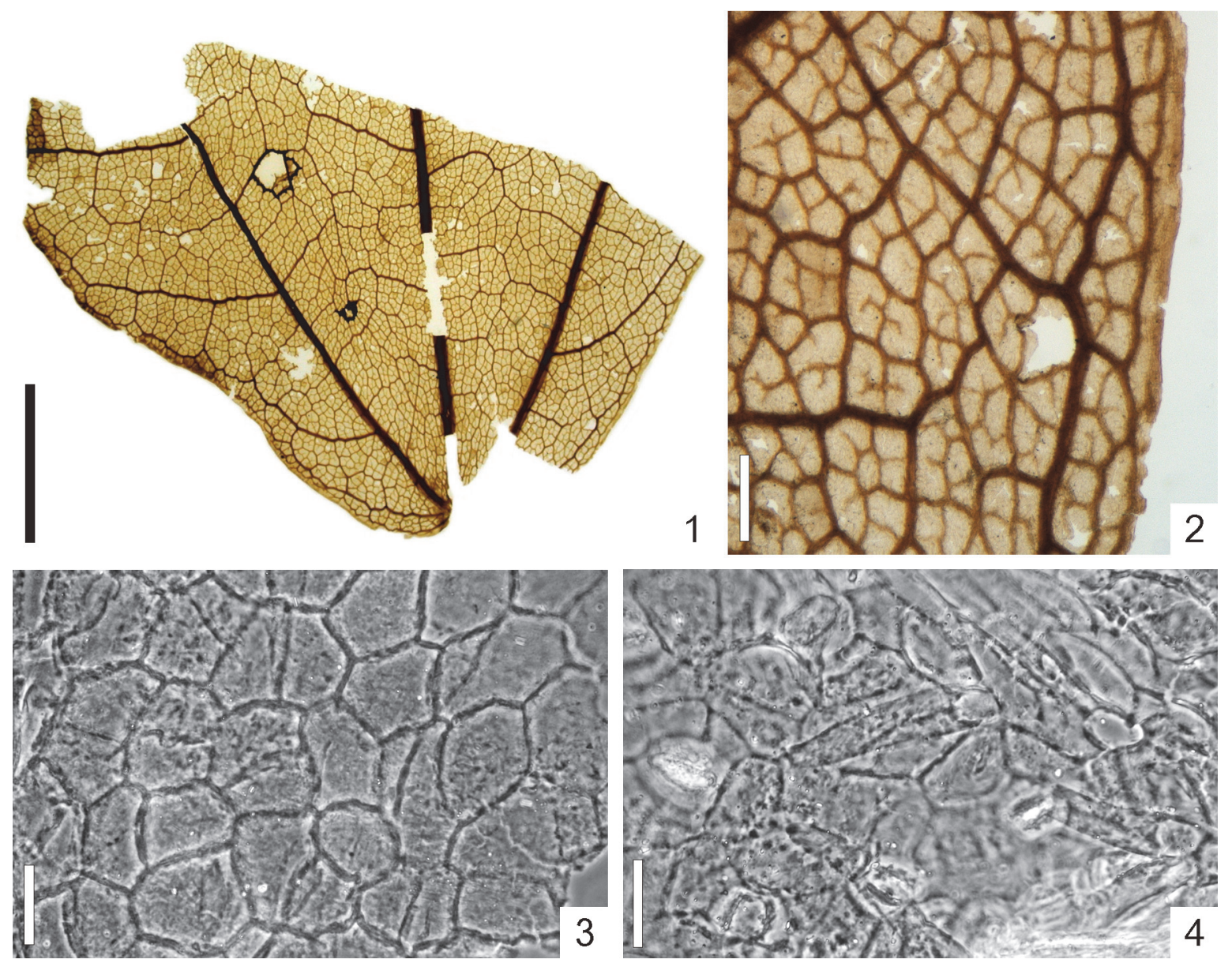

FIGURE 11. Acer tricuspidatum Bronn sensu Procházka and Bůžek: 1. Fragment of basal part of leaf, KRAM-P 225/1; 2. Detail of leaf margin venation and areolation, KRAM-P 225/1; 3. Adaxial epidermis, KRAM-P 225/1; 4. Abaxial epidermis with stomata and solitary, unicellular trichomes, KRAM-P 225/1. Scale bar equals to $0.5 \mathrm{~cm}$ for (1), $0.5 \mathrm{~mm}$ for (2), and $20 \mu \mathrm{m}$ for (3) and (4).

\section{Description}

Macromorphology. Small fragment of leaf, $1.5 \mathrm{~cm}$ by $2.2 \mathrm{~cm}$. Leaf base more or less rounded. Venation palmate, actinodromous, basal. Primary vein branched into three branches. Tertiary veins composite intersecondary. Higher-order venation random reticulate. Areoles well developed, $0.24 \mathrm{~mm}-$ $0.42 \mathrm{~mm}$ in size. Veinlets simple or once branched. Marginal ultimate venation looped.

Micromorphology. Adaxial epidermis composed of isodiametric or slightly elongated cells with mostly straight walls, $24.0 \mu \mathrm{m}-51.5 \mu \mathrm{m}$ in size, with indistinct cuticle ornamentation of parallel striae. Over veins, cells more elongated and narrow. Abaxial epidermis composed of isodiametric or slightly elongated cells, $17 \mu \mathrm{m}-37 \mu \mathrm{m}$ in size, with straight or rounded cell walls. Leaves hypostomatic. Stomata anomocytic or sometimes brachyparacytic, round- ish to elliptic, $17 \mu \mathrm{m}-22 \mu \mathrm{m}$ in size. Outer stomatal ledge aperture rather distinct and of characteristic elliptic-rectangular shape, $9.8 \mu \mathrm{m}-17.0 \mu \mathrm{m}$ long and $7.4 \mu \mathrm{m}-9.8 \mu \mathrm{m}$ wide. On abaxial epidermis, presence of numerous unicellular, simple trichomes, 54 $\mu \mathrm{m}-63 \mu \mathrm{m}$ long and ca.10 $\mu \mathrm{m}$ wide with unicellular trichome bases, ca. $12 \mu \mathrm{m}$ in size. Similar trichome bases also rarely found on adaxial epidermis.

\section{Specimens Examined}

KRAM-P 225: 1.

\section{Remarks}

The described leaf fragment is rather small, although the stomatal shape and abundant pubescence of abaxial epidermis are typical of the fossil species Acer tricuspidatum Bronn sensu Procházka and Bůžek. 


\section{Modern Equivalents}

Acer tricuspidatum is related to the extant eastern North American maple species Acer rubrum L. and Ac. saccharinum L. (Hantke, 1954; Kräusel and Weyland, 1959; Holý et al., 2012). The cuticular micromorphology of extant Ac. rubrum, Ac. saccharinum, and Ac. hyrcanum Frisch. and Mey is similar to that of Ac. tricuspidatum (Walther, 1972).

\section{Ecology}

Similarly to modern equivalents, fossil Acer tricuspidatum is considered as a warm temperate element.

\section{Occurrence}

Acer tricuspidatum is known from middle Oligocene to Pliocene plant assemblages from Europe (Procházka and Bůžek, 1975) and is frequently found in the Neogene of Poland (Worobiec et al., 2008).

Family MALVACEAE Jussieu, 1789

Fossil-genus LARIA G. Worobiec and Kvaček, 2010, in Worobiec et al. (2010)

Type Species. Laria rueminiana (Heer) G. Worobiec and Kvaček, 2010.

$$
\begin{aligned}
& \text { Laria rueminiana (Heer) G. Worobiec and Kvaček, } \\
& 2010
\end{aligned}
$$

\section{Specimens Examined}

KRAM-P 225: 7, 11, 38, 39/III, 40/I, 42/II, 43/I, 44/ III, 45/I, 46, 47/III, 48/I, 49/I, 50, 51/I, 52/I, 53, 54/I, 55/I, 56, 57, 58/III, 59, 60/IV, 61, 62, 63/I, 64/II, 65, 66/II, 67/III, 68/II, 69/I, 86/III, 87/I, 97/I. cf. Laria rueminiana: 81/I,82/I, 107/II, 110/I.

\section{Remarks}

The discussed remains of leaves of Laria rueminiana were thoroughly described, discussed, and illustrated earlier in Worobiec et al. (2010).

Family FABACEAE Lindley, 1836

Genus GLEDITSIA Clayton, J. Clayton in Linnaeus, 1753

Type Species. Gleditsia triacanthos Linnaeus, 1753.

\section{Gleditsia europaea sp. nov. G. Worobiec}

$$
\text { Figure 12.1-8 }
$$

\section{Holotype}

Specimen KRAM-P 225/16, illustrated in Figure 12.1, 12.4, 12.7-8. Stored in W. Szafer Institute of Botany, Polish Academy of Sciences, Kraków, Poland.

\section{Further Type Material}

KRAM-P 225: 3, 36, 37, 58/II, 60/III.

\section{Further Tentatively Referred Material}

cf. Gleditsia europaea sp. nov.: 100, 119/II.

\section{Synonymy}

? 1998 Ternstroemites sp., Worobiec and Lesiak, p. 192-193, PI. 2, figs. 2, 2a

2014 Dicotylophyllum sp. 1, Worobiec, p. 258, PI. 3 fig. 5, PI. 6, figs.3a-3b

2016 Dicotylophyllum sp. 1 sensu Worobiec (2014), Worobiec and Szynkiewicz, p. 457, PI. 5, figs. 1a-1b

\section{Repository}

W. Szafer Institute of Botany, Polish Academy of Sciences, Kraków, Poland, collection KRAM-P 225.

\section{Type Locality}

Bełchatów Lignite Mine, Poland.

\section{Stratigraphic Horizon}

Latest middle Miocene to late Miocene.

\section{Etymology}

Species named after Europe.

\section{Diagnosis}

Leaflets elliptic-ovate, asymmetric. Leaflet apex acute to mucronate, leaflet base obtuse to rounded, distinctly asymmetric, almost sessile. Petiolule rather short, thick. Leaflet margin crenate, veins loop reaching glands on leaflet margin. Venation pinnate. Secondary venation semicraspedodromous. Secondaries alternate, irregularly arranged, curved upwards, and interconnected in loops. Intersecondary veins sometimes present. Tertiary venation usually random reticulate, rarely composite intersecondary. Higher-order venation random reticulate. Areoles imperfectly developed, large, and rather diverse in size. Veinlets multiple branched. Marginal ultimate venation looped. Adaxial epidermis cells with straight, sometimes rounded, and thick walls. Abaxial epidermis cells with straight, rounded, or rarely wide, undulate walls. Leaflets hypostomatic. Stomata elliptic, cyclocytic, anisocytic, and paracytic. Outer stomatal ledge aperture spindle-shaped. Both adaxial and abaxial epidermis with unicellular, simple, solitary trichomes with unicellular, elliptic to roundish trichome bases. 

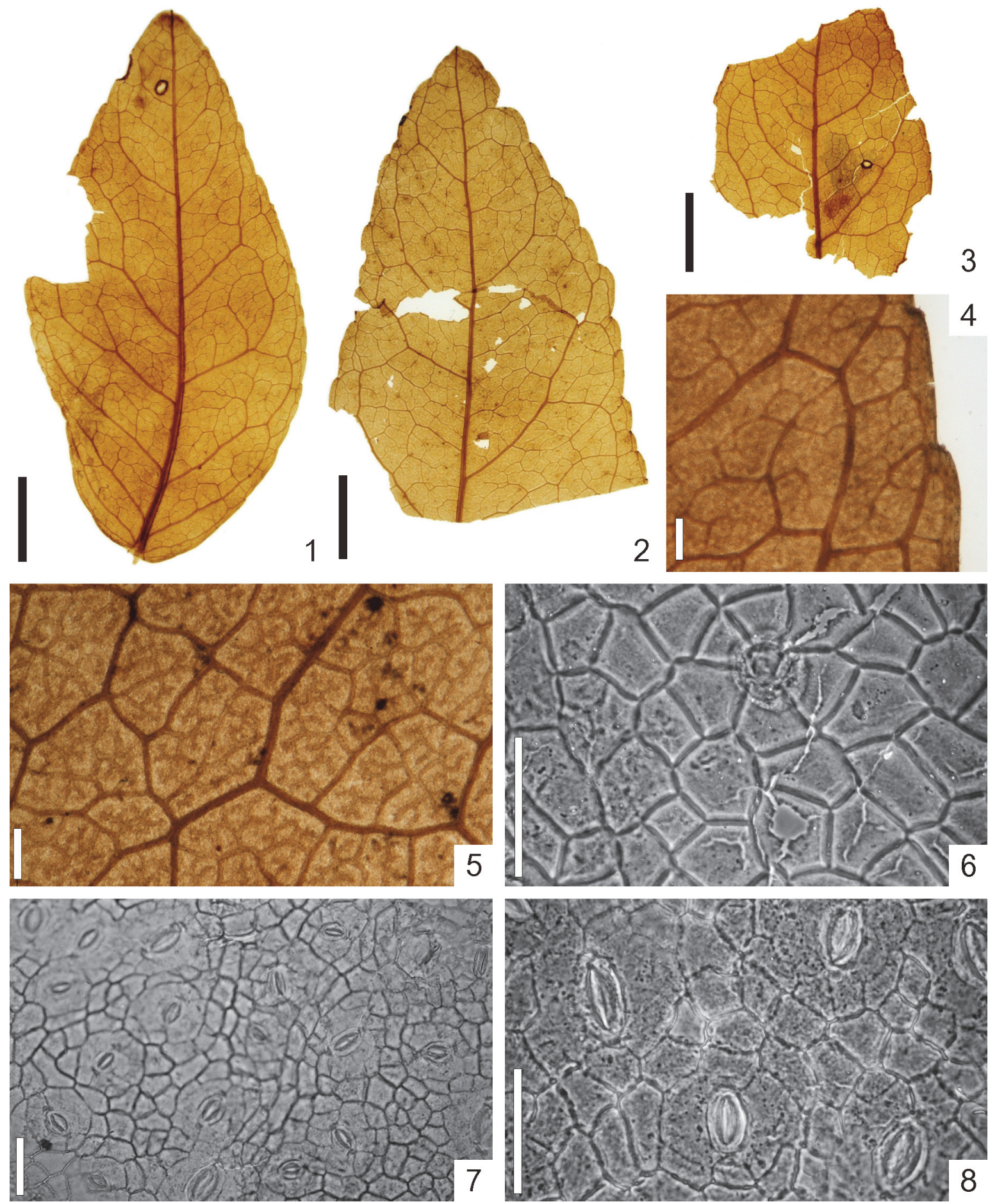

FIGURE 12. Gleditsia europaea sp. nov.: 1. Holotype, leaflet, KRAM-P 225/16; 2. Leaflet fragment, KRAM-P 225/8; 3. Leaflet fragment, KRAM-P 225/37; 4. Holotype, detail of leaflet margin and teeth venation, KRAM-P 225/16; 5. Detail of leaflet areolation, KRAM-P 225/3; 6. Adaxial epidermis, KRAM-P 225/3; 7. Holotype, abaxial epidermis with stomata, KRAM-P 225/16; 8. Holotype, abaxial epidermis with stomata, KRAM-P 225/16. Scale bar equals to $0.5 \mathrm{~cm}$ for (1), (2), and (3), $0.5 \mathrm{~mm}$ for (4) and (5), and $50 \mu \mathrm{m}$ for (6), (7), and (8). 


\section{Description}

Macromorphology. Fragments of leaflets, ellipticovate, up to $3.4 \mathrm{~cm}$ long and $1.2 \mathrm{~cm}-2.0 \mathrm{~cm}$ wide, asymmetric. Leaflet apex acute to mucronate, leaflet base obtuse to rounded, distinctly asymmetric, almost sessile. Petiolule rather short, thick. Leaflet margin crenate, veins loop reaching glands on leaflet margin. Venation pinnate, primary vein straight, and of moderate thicknees. Secondary venation semicraspedodromous. Secondaries alternate, irregularly arranged, curved upward, and interconnected in loops, forming an angle of $50^{\circ}-65^{\circ}$ with the primary vein. Intersecondary veins sometimes present. Tertiary venation usually random reticulate (rarely composite intersecondary). Higher-order venation random reticulate. Areoles imperfectly developed, large, and rather diverse in size, 0.7 $\mathrm{mm}-2.4 \mathrm{~mm}$. Veinlets multiple branched. Marginal ultimate venation looped. Presence of numerous trichomes in leaf margin of isolated leaves.

Micromorphology. Adaxial epidermis composed of isodiametric or slightly elongated cells, with straight, sometimes rounded thick walls, $17.0 \mu \mathrm{m}-51.5 \mu \mathrm{m}$ in size. Abaxial epidermis composed of isodiametric or slightly elongated cells with straight, rounded, or rarely even wide undulate walls, $19.6 \mu \mathrm{m}-44.1 \mu \mathrm{m}$ in size, over the veins cells elongated and rectangular. Leaflets hypostomatic. Stomata cyclocytic, anisocytic, and paracytic, elliptic, $25 \mu \mathrm{m}-42 \mu \mathrm{m}$ long and $14.7 \mu \mathrm{m}-19.6 \mu \mathrm{m}$ wide. Outer stomatal ledge aperture spindle-shaped, $17.2 \mu \mathrm{m}-34.3 \mu \mathrm{m}$ long and $4.9 \mu \mathrm{m}-17.2 \mu \mathrm{m}$ wide. On both adaxial and abaxial epidermis, presence of unicellular, simple, solitary trichomes (on abaxial epidermis, $90 \mu \mathrm{m}-245 \mu \mathrm{m}$ long and $9.0 \mu \mathrm{m}-14.7 \mu \mathrm{m}$ wide). Unicellular, elliptic to roundish trichome bases, $25 \mu \mathrm{m}-32 \mu \mathrm{m}$ (adaxial epidermis) and $19.6 \mu \mathrm{m}-24.5 \mu \mathrm{m}$ (abaxial epidermis) in diameter.

\section{Remarks}

Characteristically asymmetrical leaflet base, short petiolule, crenate margin, and network of secondary and third order venation are overall similar to the condition seen in extant species of the genus Gleditsia L. Cuticular micromorphology also matches well extant species of Gleditsia (Barclay et al., 2017). Similar fossil leaflets were described from Miocene deposits of Europe and Japan as Gleditsia sp. (Hably and Kvaček, 1997; Kvaček et al., 2011), Gleditsia miosinensis Hu and Chaney (Yabe, 2008), and Leguminosites sp. (Kvaček et al., 2008). Among them only Gleditsia sp. described from the Miocene flora of Arjuzanx, France (Kvaček et al., 2011) and
Leguminosites sp. found in the Pliocene flora of Auenheim, France (Kvaček et al., 2008) are sufficiently well preserved to be reliably compared with Gleditsia leaflets from Bełchatów. Moreover, leaflets of Leguminosites sp. from Auenheim are accompanied by thorn remains described as cf. Gleditsia sp. Macromorphologically, leaflets from Arjuzanx, Auenheim, and Belchatów are rather similar and the observed differences between them could be caused both by intra- and inter-specific variability. However, there are no data about the cuticular micromorphology of the discussed legume leaflets from Arjuzanx and Auenheim. Contrary to these fossils, the leaflets of Gleditsia from Bełchatów display excellently preserved cuticular structures. Considering this, we decide to erect a new taxon. The remaining fossil record of the Gleditsia genus (leaflets, woods, spines, pollen grains) is rather scarce, partly poorly preserved, and in many cases, taxonomical determination of these fossils is doubtful. The oldest fossils of Gleditsia are known from Oligocene, and the best documented is the Miocene record from North America, Eastern Asia, and Caucasus (Schnabel et al., 2003).

\section{Modern Equivalents}

The fossil Gleditsia europaea sp. nov. is most similar to the extant North American species Gleditsia aquatica Marshall in terms of leaflet shape, margin crenation, and density of secondary veins as well as the cuticular micromorphology. Gleditsia aquatica is an obligatory wetland species (Lichvar, 2013) found in wetland forest vegetation of south and southeastern USA (USDA Plants Database, 2017).

\section{Ecology}

Similarly to extant Gleditsia aquatica Marshall, fossil Gleditsia europaea sp. nov. is considered as a warm temperate element, component of wetland vegetation.

Fossil-genus LEGUMINOPHYLLUM A. EscalupBassi, 1971

Type Species. Leguminophyllum emarginatum A. Escalup-Bassi, 1971.

Leguminophyllum kvacekii sp. nov. G. Worobiec Figure 13.1-8

\section{Holotype}

Specimen KRAM-P 225/22, illustrated on Figure 13.1. Stored in W. Szafer Institute of Botany, Polish Academy of Sciences, Kraków, Poland. 

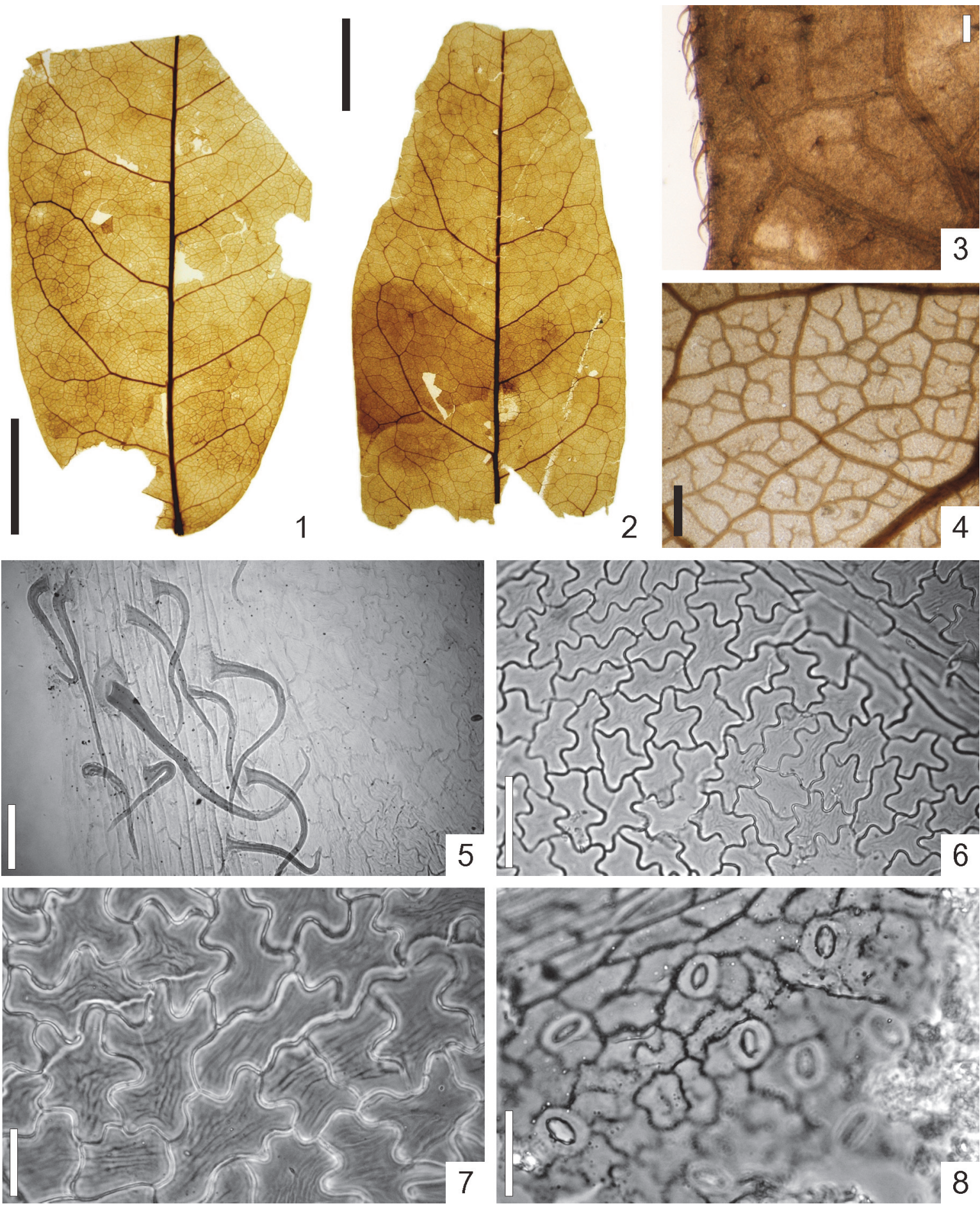

FIGURE 13. Leguminophyllum kvacekii sp. nov.: 1. Holotype, leaflet fragment, KRAM-P 225/22; 2 . Leaflet fragment, KRAM-P 225/14; 3. Detail of leaflet margin with large trichomes, KRAM-P 225/14; 4. Detail of leaflet areolation, KRAM-P 225/5; 5. Adaxial epidermis with large trichomes over the veins, KRAM-P 225/4; 6. Adaxial epidermis, undulate cell walls, KRAM-P 225/17; 7 . Adaxial epidermis, note striate ornamentation of cuticle, KRAM-P 225/17; 8. Abaxial epidermis with stomata, KRAM-P 225/17. Scale bar equals to $1 \mathrm{~cm}$ for (1) and (2), $0.5 \mathrm{~mm}$ for (4), $0.1 \mathrm{~mm}$ for (3), $50 \mu \mathrm{m}$ for (5) and (6), and $20 \mu \mathrm{m}$ for (7) and (8). 


\section{Further Type Material}

KRAM-P 225: 4, 5, 6, 9, 10, 14, 17, 20, 21, 25, 51/ II, 58/IV, 60/N, 66/III, 68/III, 72/III, 75/II, 85/I, 86/IV, 107/III, 113, 127.

\section{Synonymy}

? 2016 Dicotylophyllum sp. 4, Worobiec and Szynkiewicz, p. 458-459, pl. 5, figs. 4a-b, pl. 13, figs. $4 a-4 c$

\section{Repository}

W. Szafer Institute of Botany, Polish Academy of Sciences, Kraków, Poland, collection KRAM-P 225.

\section{Type Locality}

Bełchatów Lignite Mine, Poland.

\section{Stratigraphic Horizon}

Latest middle Miocene to late Miocene.

\section{Etymology}

Named after the eminent Czech palaeobotanist Professor Zlatko Kvaček in recognition of his contribution to Paleogene and Neogene palaeobotany on the occasion of his eighteenth birthday.

\section{Diagnosis}

Leaflets asymmetric, entire-margined, margin covered by large trichomes. Leaflet base distinctly asymmetric, obtuse sometimes rounded or nearly cordate, short petiolulate or sessile. Venation pinnate, primary vein straight or bent. Secondary venation brochidodromous. Secondaries curved upwards and interconnected in loops, distributed at irregular intervals. Intersecondary veins present, distinct. Tertiary venation composite intersecondary. Higher-order venation reticulate. Areoles well developed, diverse in size. Veinlets usually multiple branched, sometimes simple. Marginal ultimate venation looped. Adaxial epidermis cells walls undulate, rarely straight and rounded, cuticle with distinct striate ornamentation. Abaxial epidermis cells with straight, rounded to undulate cell walls. Leaves hypostomatic. Stomata anomocytic, elliptic. Outer stomatal ledge aperture elliptic, sometimes wide spindle-shaped. Unicellular, simple, solitary trichomes in abaxial epidermis, unicellular trichome bases in both adaxial and abaxial epidermis.

\section{Description}

Macromorphology. Entire-margined (sometimes margin sinuous) leaflets, asymmetric, up to $5.7 \mathrm{~cm}$ long and $2.6 \mathrm{~cm}-3.7 \mathrm{~cm}$ (rarely $4.0 \mathrm{~cm}$ ) wide. Leaflet margin covered by large trichomes. Leaflet base obtuse sometimes rounded or nearly cordate, distinctly asymmetric, short petiolulate or sessile. Venation pinnate, primary vein straight or bent, and of moderate thickness. Secondary venation brochidodromous. Secondaries curved upwards and interconnected in loops, preserved in up to seven pairs, distributed at irregular intervals of $0.3 \mathrm{~cm}-0.4 \mathrm{~cm}$ near leaflet base and $0.6 \mathrm{~cm}-1.4 \mathrm{~cm}$ in the middle of the lamina, forming an angle of $60^{\circ}-80^{\circ}$ with the primary vein. Intersecondary veins present, distinct. Tertiary venation composite intersecondary. Higherorder venation reticulate. Areoles well developed, diverse in size, $0.4 \mathrm{~mm}-1.0 \mathrm{~mm}$ (rarely $1.2 \mathrm{~mm}$ ). Veinlets usually multiple branched, sometimes simple. Marginal ultimate venation looped.

Micromorphology. Adaxial epidermis composed of isodiametric or slightly elongated cells, with undulate, rarely straight or rounded walls, $22.0 \mu \mathrm{m}-58.8$ $\mu \mathrm{m}$ in size. Cuticle of adaxial epidermis with distinct striate ornamentation. Abaxial epidermis composed of isodiametric or slightly elongated cells with straight, rounded to undulate cell walls, $19.6 \mu \mathrm{m}-$ $36.8 \mu \mathrm{m}$ in size. Over the veins, cells elongated and rectangular. Leaves hypostomatic. Stomata anomocytic, elliptic to wide elliptic, $22.0 \mu \mathrm{m}-26.9 \mu \mathrm{m}$ in size. Stomatal pore usually visible. Outer stomatal ledge aperture elliptic, sometimes wide spindleshaped, $11.0 \mu \mathrm{m}-19.6 \mu \mathrm{m}$ long and $4.9 \mu \mathrm{m}-9.8 \mu \mathrm{m}$ wide. Presence of unicellular, simple, solitary trichomes, $98 \mu \mathrm{m}-245 \mu \mathrm{m}$ long and up to $17 \mu \mathrm{m}$ wide in the basal part of the abaxial epidermis. Presence of presumably unicellular trichome bases, $34.3 \mu \mathrm{m}-$ $44.1 \mu \mathrm{m}$ in size, on both adaxial and abaxial epidermis.

\section{Remarks}

The above described leaflets are short petiolulate or sessile, which is typical for fossil legume leaflets usually assigned to the fossil-genus Leguminosites Bowerbank emend. Schimper. The initial name Leguminosites was used for legume carpological remains but later also for leaflets. However, according to Wang (2012), fossil-genus Leguminosites name, due to nomenclatural rules, should not be used for legume leaflet fossils. Instead, Wang (2012) suggested using the fossil genera names Leguminophyllum A. Escalup-Bassi and Parvileguminophyllum Herendeen and Dilcher for fossil leaflets of Fabaceae. Considering this, we decided to attribute the legume leaflets from Bełchatów to the fossil-genus Leguminophyllum, which has priority over Parvileguminophyllum. The epidermal micromorphology of Leguminophyllum 
kvacekii sp. nov. matches well the micromorphology of various members of extant (Barclay et al., 2017) and fossil (e.g., Kvaček et al., 2011) Fabaceae. Leguminophyllum kvacekii sp. nov. leaflets are nearly identical in both macromorphology and cuticular structure to leaflets earlier described from middle to late Miocene leaf assemblage from the Bełchatów mine as Dicotylophyllum sp. 4 (Worobiec and Szynkiewicz, 2016), and they are therefore likely conspecific. Another fossil taxon of legume leaflets from the Neogene deposits of Bełchatów, Dicotylophyllum sp. 1 (Worobiec et al., 2012), probably conspecific with Dicotylophyllum sp. 3 (Worobiec and Szynkiewicz, 2016), differs from Leguminophyllum kvacekii sp. nov. mainly in its considerably smaller areoles. The well-preserved legume leaflets described as Leguminosites sp. B, Leguminosites sp. G, and Leguminosites sp. $\mathrm{H}$ from the Miocene flora of Arjuzanx, France (Kvaček et al., 2011), are also similar to Leguminophyllum kvacekii sp. nov. Among them, Leguminosites sp. H. seems to be macromorphologically closest to Leguminophyllum kvacekii sp. nov. Unfortunately, there are no data on the epidermal structure of Leguminosites sp. $\mathrm{H}$ and, therefore, the relationships between those two fossil taxa cannot be conclusively clarified. Leguminophyllum kvacekii sp. nov. differs from the fossil-genera of similar Fabaceae leaflets, Podocarpium A. Braun ex Stizenberger and Phaseolites Unger, in density and the course of the secondary venation network. In addition, for most of the leaflets described as Phaseolites and Podocarpium, there are no data on their epidermis. Other fossil genera considered as legume leaflets, such as Bauhinites Seward and Conway, Dalbergites E. W. Berry, Diphyllites Heer, Diplophyllum
Velenovsky and Viniklar, Fontainea Newberry, and Podalyriophyllum Ettingshausen, were reported mostly from Cretaceous deposits, usually have no data on cuticles, and therefore their placement among Fabaceae seems doubtful.

\section{Modern Equivalents}

The exact systematic position of the leaflets attributed to Leguminophyllum kvacekii sp. nov. is unknown as leaflets of this macro- and micromorphology are common among extant Fabaceae genera and, as such, they are hardly assignable to any natural taxon.

\section{Ecology}

Unknown.

Dicotyledones incertae sedis

Fossil-genus DICOTYLOPHYLLUM Saporta, 1894

Type Species. Dicotylophyllum cerciforme Saporta, 1894.

\section{Dicotylophyllum sp. 1}

Figure 14.1-3

\section{Description}

Macromorphology. Badly preserved, small fragment $(\mathrm{ca} .1 \mathrm{~cm})$ of basal part of serrate leaf. Vein loop reaching sinus between teeth. Veinlets branched.

Micromorphology. Adaxial epidermis composed of slightly elongated cells with one papilla in each cell, with undulate walls, $41.7 \mu \mathrm{m}-56.4 \mu \mathrm{m}$ in size. Cuticle of adaxial epidermis covered by epicuticular wax. Abaxial epidermis similar in terms of morphology to adaxial epidermis, with undulate cell walls. Leaves hypostomatic. Stomata elliptic to wide elliptic, 26.9
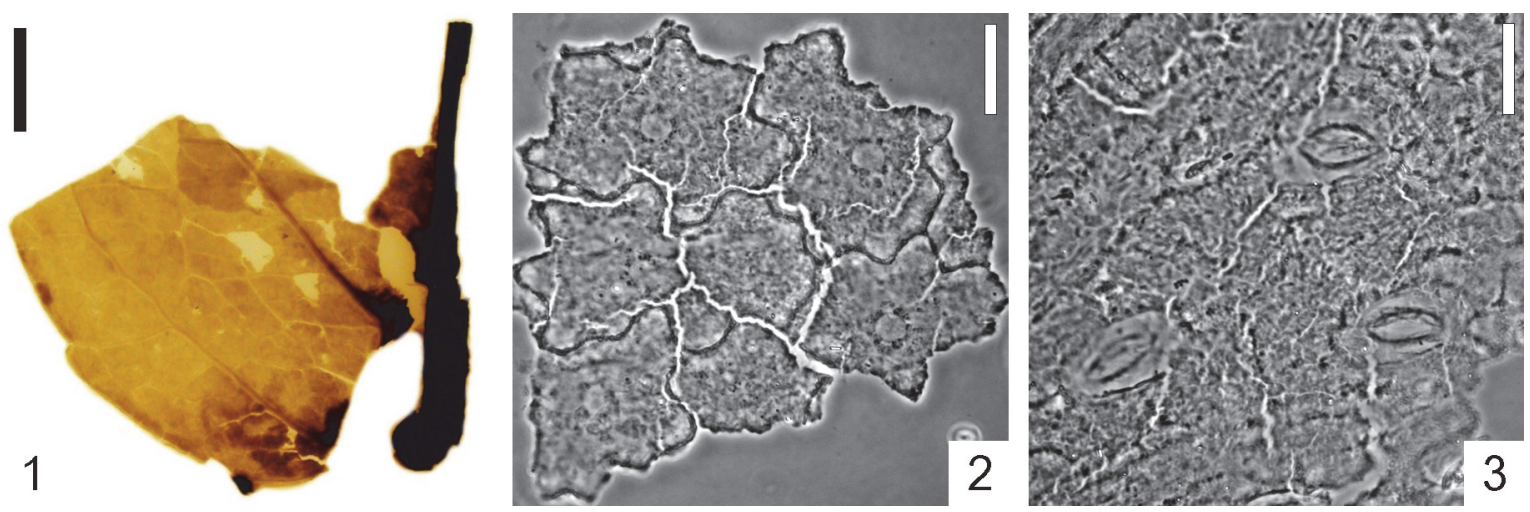

FIGURE 14. Dicotylophyllum sp. 1: 1. Fragment of basal part of leaf, KRAM-P 225/13; 2 . Adaxial epidermis, note papillae in each cell, KRAM-P 225/13; 3. Abaxial epidermis with stomata, KRAM-P 225/13. Scale bar equals to 2 mm for (1), and $20 \mu \mathrm{m}$ for (2) and (3). 
$\mu \mathrm{m}-31.9 \mu \mathrm{m}$ in size. Outer stomatal ledge aperture spindle-shaped to elliptic, $12.2 \mu \mathrm{m}-22.0 \mu \mathrm{m}$ long and $7.4 \mu \mathrm{m}-11.0 \mu \mathrm{m}$ wide.

\section{Specimens Examined}

KRAM-P 225: 13.

\section{Remarks} unknown.

The systematic position of the leaf remain is Dicotyledones indet.

\section{Specimens Examined}

KRAM-P 225: 83/III, 92/I.

\section{Remarks}

The discussed leaf remains are poorly preserved, without distinctive characters. Their systematic position is unknown.

Clade PETROSAVIIDAE S.W. Graham and W.S. Judd, 2007, in Cantino et al. (2007)

Family POACEAE Barnhart, 1895

Genus PHRAGMITES Adanson, 1763

Type Species. Phragmites communis Trinius, 1820.

Phragmites oeningensis A. Braun, Stizenberger, 1851

Figure 15.1

\section{Description}

Macromorphology. Rather small and badly preserved fragments of linear, entire-margined leaves, up to $8.0 \mathrm{~cm}$ long and ca. $0.8 \mathrm{~cm}$ wide. Venation parallelodromous. Midvein rarely preserved. Lateral veins spaced $0.7 \mathrm{~mm}-1.0 \mathrm{~mm}$ apart, with 3-4 (close to leaf margin) to 5-6 (in the middle part of the lamina) third order veins lying between them, spaced $0.12 \mathrm{~mm}-0.18 \mathrm{~mm}$ apart. Cross (transverse) veins absent.

\section{Specimens Examined}

KRAM-P 225: 44/V, 93/IV, 106/III.

\section{Remarks}

The above described monocotyledonous leaves with parallelodromous venation without cross veins point to the fossil species Phragmites oeningensis A. Braun.

\section{Modern Equivalents}

Common reed Phragmites communis Trin. is considered as a recent equivalent of fossil Phragmites oeningensis (Krajewska, 1998).

\section{Ecology}

Similarly to modern equivalent, fossil Phragmites oeningensis is considered as a temperate element.

\section{Occurrence}

Phragmites oeningensis was common in the Paleogene and Neogene of Europe. In Poland it was reported from middle to late Miocene deposits (Worobiec et al., 2008).

Family POTAMOGETONACEAE Berchtold and J. Presl, 1823

Genus POTAMOGETON Linnaeus, 1753

Type Species. Potamogeton natans Linnaeus, 1753.

\section{Potamogeton sp.}

Figure 15.2-7

\section{Description}

Macromorphology. Fragments of entire-margined leaves, up to $2.7 \mathrm{~cm}$ long and ca. $1 \mathrm{~cm}$ wide. Leaf apex acute to attenuate, leaf base decurrent, petiole broad and rather long. Leaf venation parallelodromous. Midvein present, straight and thin, 67 lateral veins spaced $0.12 \mathrm{~mm}-0.30 \mathrm{~mm}$ apart (close to leaf margin) to $0.50 \mathrm{~mm}-1.20 \mathrm{~mm}$ (in the middle part of the lamina) lying on each side of the midvein. Usually oblique transverse veins spaced $0.5 \mathrm{~mm}-1.0 \mathrm{~mm}$, connecting adjacent lateral veins. Besides these comparatively broad leaves in some of the rock samples (e.g., 225/58, 225/71), presence of small fragments of narrow (up to $2 \mathrm{~mm}$ wide) linear leaves with venation typical of Potamogeton. Presumably narrow, submerged leaves or phyllodes of the same or other species.

Micromorphology. Leaves without stomata. Epidermis seemingly uniform on both sides of the leaves. Epidermal cells rectangular, up to $25 \mu \mathrm{m}$ long and $5.0 \mu \mathrm{m}-12.5 \mu \mathrm{m}$ wide. Anticlinal cell walls straight or rounded. Surface of the epidermis covered by sparse grains of epicuticular wax.

\section{Specimens Examined}

KRAM-P 225: 23, 58/VI, 60/VII, 71/IV, 86/VI, 92/II, 93/V, 94/III, 106/IV, 119/IV, 124.

\section{Remarks}

The described leaf remains display venation architecture and epidermal cell arrangement typical of genus Potamogeton. The mixture of different morphological forms of Potamogeton leaf fossils could have originated from different species or could have resulted from the heterophylly of leaves 

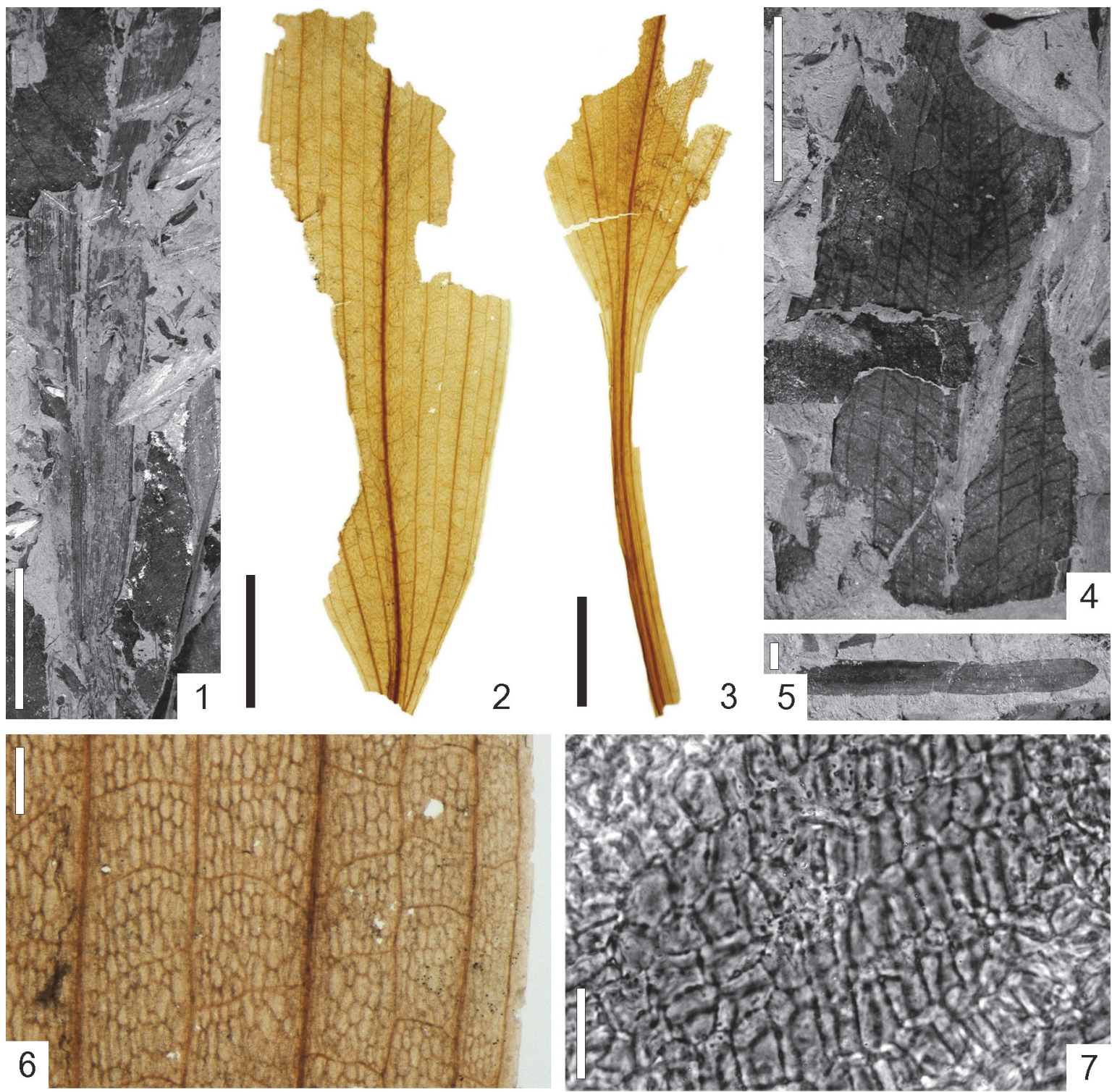

FIGURE 15. Phragmites oeningensis A. Braun: 1. Leaf fragment, KRAM-P 225/93/IV. Potamogeton sp.: 2. Leaf fragment, KRAM-P 225/23; 3. Leaf fragment, KRAM-P 225/23; 4. Leaf fragment, KRAM-P 225/106/IV; 5. Fragment of submerged leaf or phyllode, KRAM-P 225/58/VI; 6. Detail of leaf venation and leaf margin, KRAM-P 225/23; 7. Epidermis, KRAM-P 225/23. Scale bar equals to $1 \mathrm{~cm}$ for (1), $0.5 \mathrm{~cm}$ for (2), (3), and (4), $1 \mathrm{~mm}$ for (5), $0.5 \mathrm{~mm}$ for (6), and $20 \mu \mathrm{m}$ for (7).

typical of some species of Potamogeton (Les and Sheridan, 1990). They certainly represent pondweed species with submerged leaves, which is corroborated by a complete absence of stomata on both sides of the leaf epidermis (comp. Haynes et al., 1998). Miocene leaves of Potamogeton martinianus Sitár from Reith, Austria (Kovar-Eder and Krainer, 1991), Potamogeton sp. from Prosilio, Greece (Velitzelos et al., 2014), and Potamogeton sp. from Tossignano and Monte Tondo, Italy (Teodoridis et al., 2015) differ from Potamogeton sp. from Bełchatów in their considerably wider leaves. Similar differences are observed with leaves of Potamogeton aff. perfoliatus L. from Konin, Poland (Raniecka-Bobrowska, 1954). The remaining fossils of Potamogeton leaves from Poland, Potamogeton martinianus Sitár (Zastawniak, 1980) and Potamogeton sp. (Kownas, 1956), both from middle Miocene deposits, are too badly preserved to be compared with pondweed leaves from Bełchatów. Leaves of Potamogeton praenatans Knoll from Most Basin, Czech Republic (Teodoridis, 2007) are somewhat similar in shape and width to Potamogeton sp. from Bełchatów. 
Nevertheless, due to the rather fragmentary nature of Potamogeton leaf remains from Bełchatów, we cannot match the discussed remains and fossil leaves of Potamogeton from other localities.

\section{Modern Equivalents}

Due to the rather fragmentary nature of the leaves of Potamogeton sp., any recent pondweed equivalent could not be established.

\section{Ecology}

Potamogeton sp. from Bełchatów is considered to be a temperate element. Similarly to recent representatives of Potamogeton, pondweed from Bełchatów was certainly an aquatic plant (Haynes et al., 1998).

\section{Occurrence}

According to Daghlian (1981), the fossil remains of Potamogeton (mainly seeds) were reported worldwide from Oligocene deposits. The leaves of this genus in Europe, however, were reported beginning from the late Eocene, and they occur most frequently in Neogene deposits (Teodoridis, 2007). Pre-Cenozoic reports concerning macroremains of Potamogeton are considered to be doubtful (Daghlian, 1981). In Poland, fossil Potamogeton leaves were reported from middle Miocene deposits of Dobrzyń on the Vistula River (Kownas, 1956), Konin (Raniecka-Bobrowska, 1954), and Młyny (Zastawniak, 1980).

\section{TAPHONOMY}

The remains of leaves from the KRAM-P 225 assemblage were preserved as compressions and impressions. An accumulation of leaves may have originated from seasonal leaf fall from trees and shrubs directly surrounding a fluvial lake (most probably a water body with stagnant or slowly moving water). The transport of fallen leaves into a water body by flood waters or by strong winds from more distant places could also have happened. The plant assemblage studied here was presumably formed in an abandoned channel of a meandering river (oxbow lake) or braided river (comp. Wilczyński, 1992 and Krzyszkowski and Winter, 1996). A plant assemblage (oryctocoenosis) of this type is considered to be parautochthonous (Gastaldo et al., 1996).

\section{CHARACTERISTICS OF PALAEOVEGETATION}

A reliable reconstruction of the palaeovegetation must take into account the form of fossil remains (which limits the range of possible transport by wind or water), the sedimentary environment that limits the possible habitats, and the ecology of the nearest living relatives of fossil taxa (Ferguson et al., 1998). Most macroremains analysed from assemblage KRAM-P 225 are fossil leaves, usually from trees and shrubs, with a limited dispersal potential that did not exceed 20-50 m from the source plant (Ferguson, 1985). The plant assemblage KRAM-P 225 was most probably formed in the fluvial sedimentary environment of a water body with stagnant (fluvial lake in abandoned channel) or slowly flowing water (fluvial lake in abandoned channel partially or temporarily connected with river). In the case of a fluvial sedimentary environment, leaf assemblages of wetland vegetation surrounding a sedimentary reservoir bear little resemblance to the vegetation as a whole (Spicer, 1980; Ferguson, 1985). Leaf floras formed in deposits of a similar type of sedimentary environment reflect both the autochthonous aquatic vegetation (water plants) and the vegetation cover of habitats that directly surround the water body (Ferguson et al., 1998). The analysis of the ecology of the nearest living relatives of fossil taxa could help to distinguish taxa found in the discussed plant assemblage as components of swamp, riparian, or mesophytic plant communities. It should be stressed, however, that fossil plant assemblages from fluvial environments of abandoned channels are composed almost exclusively of remains of wetland vegetation that grow along the channel margins (Behrensmeyer and Hook, 1992). Thus, the presence and presumably composition of mesophytic (zonal) plant communities can be inferred only indirectly using taxa that represent the "mesophytic" component of wetland plant communities (Worobiec and Szynkiewicz, 2016). Wetland vegetation of a fluvial (riverine) environment is shaped mostly by the duration of floods and the associated variation of groundwater levels (Theriot, 1993; Cooper and Merritt, 2012). The frequency and duration of flood inundation and raised groundwater levels depend directly on the elevational gradient of the river floodplain and strongly influence the distribution of plant species in wetland communities. Considering this, Reed (1988), Tiner (1993), and Lichvar (2013) established five wetland indicator status ratings for plants occurring in natural conditions for the USA's National Wetland Plant List. In the case of fossil plant communities, however, such a detailed rating of wetland taxa does not seem credible since most extant wetland species can be found both in rather wet and more mesic localities, even in mesophytic upland communities (Tiner, 1993). Therefore, Worobiec and Szynkiewicz (2016) proposed a simplified 
ranking for fossil wetland species with only two ranks: obligate wetland plants $(\mathrm{OW})$, which occur exclusively or almost exclusively in wetlands, and facultative wetland plants (FW), which besides inhabiting drier bottomland hardwood communities also possibly grow in upland mesophytic communities. Table 1 ranks wetland species from assemblage KRAM-P 225, mainly on the basis of the flood tolerance of modern North American equivalents of the fossil taxa, partly based on the already noted American National Wetland Plant List (Lichvar, 2013), Stults and Axsmith (2015), and Elliott et al. (2016). Potamogeton, an obligate wetland plant found in the discussed assemblage, points to the presence of water body vegetation of stagnant or slowly moving water. The remaining fossil taxa suggest that the sedimentary reservoir was surrounded by wetland (riparian) communities of a periodically flooded bottomland hardwood forest. In moist places it was probably dominated by Acer tricuspidatum, Betula cf. plioplatyptera, Betula subpubescens, Carpinus grandis, Carpinus sp., Carya serrifolia, cf. Cercidiphyllum crenatum, Gleditsia europaea sp. nov., Laria rueminiana, Myrica lignitum, Phragmites oeningensis, Pinus sp., and Sequoia abietina. Gleditsia europaea sp. nov. and Phragmites oeningensis most probably occupied the shore of the water body and were accompanied by Acer tricuspidatum, Carya serrifolia, and Myrica lignitum. In drier places, the bottomland vegetation was presumably mixed with more mesophytic taxa such as Carpinus grandis, Pinus sp., and Sequoia abietina. The wetland (riparian) forests similar to assemblage KRAM-P 225 were common in the Miocene of the Polish Lowlands (Worobiec and Kasiński, 2009). The Miocene vegetation from Bełchatów has much in common with riparian communities of eastern and south-eastern North America (Wilen and Tiner, 1993; Hamel and Foti, 1995). It also has some relationship (presumably presence of Cercidiphyllum) with the riparian communities of central China (Wei et al., 2010).

Taxa considered to be exclusively upland (zonal, mesophytic) seem to be completely absent from the discussed fossil assemblage. Presumably, the sedimentary reservoir may have been situated away from any elevations such as river terraces or upland slopes covered by mesophytic communities. Nonetheless, Alnus ducalis and Fagus silesiaca, whose remains were rather scarce, most probably occupied dry habitats in transition between riparian forest and upland mesophytic communities (Elliott et al., 2016). As most of the remaining taxa were classified as facultative wetland species, some of them

TABLE 1. Ranks of wetland species from assemblage KRAM-P 225. In the case of fossil taxa with modern equivalents from North America, the wetlands ranks are based on the flood tolerance of these equivalents (Lichvar, 2013; Stults and Axsmith, 2015; Elliott et al., 2016).

\begin{tabular}{lcc}
\hline \multicolumn{1}{c}{ Fossil taxon } & $\begin{array}{c}\text { Obligate } \\
\text { wetland }\end{array}$ & $\begin{array}{c}\text { Facultative } \\
\text { wetland }\end{array}$ \\
\hline Acer tricuspidatum & + \\
Alnus ducalis & + \\
Betula cf. plioplatyptera & + \\
Betula subpubescens & + \\
Carpinus grandis & + \\
Carpinus sp. & + \\
Carya serrifolia & & + \\
cf. Cercidiphyllum crenatum & + \\
Dicotylophyllum sp. 1 & & $?$ \\
Fagus silesiaca & + & + \\
Gleditsia europaea sp. nov. & + \\
Laria rueminiana & $?$ & + \\
Leguminophyllum kvacekii sp. nov. & + \\
Myrica lignitum & & + \\
Phragmites oeningensis & & + \\
Pinus sp. & & + \\
Potamogeton sp. & & + \\
Sequoia abietina & & + \\
\hline & & + \\
\hline
\end{tabular}


may also have been components of mesophytic upland communities.

This reconstruction of fossil vegetation based on the macroremains assemblage is in accordance with the results of a pollen analysis of samples taken from assemblage KRAM-P 225. Among the pollen, Pinaceae (mainly Pinus, Cathaya, Tsuga, and Abies) and Cupressaceae (Taxodium/Glyptostrobus type and Sequoia/Sequoiadendron/Metasequoia type) prevail. Pollen grains of angiosperms from the genera Betula, Fagus, Pterocarya, Carya, Myrica, Carpinus, Alnus, Ulmus, and Nyssa are relatively frequent. In addition, the pollen grains of Celtis, Liquidambar, Acer, Salix, Fraxinus, Eucommia, Reevesia, Cercidiphyllum, and Fabaceae (fossil species Tricolporopollenites fallax and Tr. liblarensis) and others are also present. The occurrence of some freshwater algae as well as the pollen of Potamogeton, Sparganiaceae/Typhaceae type, and Nuphar confirm the presence of a freshwater body. The pollen spectra show the dominance of wetland, riparian, and swamp vegetation. However, some genera recorded in both pollen and macroremains assemblages (Acer, Betula, Eucommia, Fagus, Quercus, Ulmus) could grow in both swamp and mesophytic plant communities. Palynological assemblage will be discussed in detail in a separate article.

\section{PALAEOCLIMATE RECONSTRUCTION}

Thermal climatic conditions (e.g., cold-month mean temperature, lowest winter temperature) have an influence on azonal wetland vegetation (Tepley et al., 2004; Schnitzler et al., 2005). Almost all fossil taxa found in assemblage KRAM-P 225 represent temperate or warm temperate elements, equivalent to the former arctotertiary geofloristic elements (Mai, 1995; Grímsson et al., 2015). The nearest living relatives of these fossil species are found in temperate to warm temperate climate areas of the Northern Hemisphere characterised by " $C$ " (warm temperate elements) and mild varieties of " $D$ " (temperate elements) climate types in the Köppen-Geiger climate classification (Kottek et al., 2006). The absence of typically thermophilous plants (e.g., Lauraceae, palms) confirms climatic cooling during the late Miocene (Prista et al., 2015) and points to warm temperate climate conditions during the sedimentation of the deposits with the discussed leaf assemblage. All the same, the presence of Gleditsia europaea sp. nov., Laria rueminiana, and Sequoia abietina, and presumably presence of Cercidiphyllum crenatum indicate favourable climatic conditions with presumably mild winters. We used the coexistence approach (CA) method (Mosbrugger and Utescher, 1997) to estimate the mean annual temperature (MAT) for the discussed leaf assemblage. In Table 2 we compare data on the fossil taxa and their recent counterparts with their MAT ranges for most taxa based on Utescher and Mosbrugger (2017) and for Cercidiphyllum japonicum and Fagus hayatae on Fang et al. (2011). As a result we estimate the MAT range as $13.5^{\circ} \mathrm{C}-16.5^{\circ} \mathrm{C}$ (lower limit for Reevesia sp. and upper limit for Betula pubescens).

Unfortunately, reconstruction of palaeoprecipitation using macroremains as a basis for azonal, wetland vegetation from Bełchatów, does not seem credible. Contrary to the vegetation of mesophytic habitats that depends mostly on water from rainfall, wetland plants take advantage of the riverine water supply and thus are not so sensitive to precipitation amounts (Brinson et al., 1981).

The palaeoclimate experienced by plant assemblage KRAM-P 225 from Bełchatów may be comparable to the modern climate of areas of deciduous broad-leaved forests with a warm temperate and humid climate. The palaeovegetation of leaf assemblage KRAM-P 225 could correspond to the extant biome of temperate deciduous (summergreen) forests (Box and Fujiwara, 2013). Recent equivalents of the fossil taxa from Bełchatów might be found in warm temperate deciduous forests of eastern North America (eastern deciduous forests, southern mixed hardwood forests), East Asia (central Japan, eastern central China - temperate deciduous forests, Mixed Mesophytic Forests) and the Euxine-Hyrcanian region (deciduous Colchis and Hyrcanian forests) (Greller, 2013; Box and Fujiwara, 2015). The climate of these areas corresponds to the Cfa type (warm temperate, fully humid, and with a hot summer) in the Köppen-Geiger climate classification (Kottek et al., 2006).

\section{AGE OF THE PLANT ASSEMBLAGE}

The analysed leaf assemblage from the Bełchatów Lignite Mine is situated at the floor part of a sandy-clayey unit whose age is estimated as late Miocene. The composition of leaf assemblage KRAM-P 225 corresponds to late Miocene leaf assemblages found earlier in a sandy-clayey unit from the Bełchatów Lignite Mine (Stuchlik et al., 1990; Worobiec and Lesiak, 1998; Worobiec, 2003b; Worobiec et al., 2012; Worobiec, 2014). Taxa representing a warm temperate, deciduous floristic element present in leaf assemblage KRAMP 225 are typical of the late Neogene vegetation of Central Europe (Mai, 1995; Kovar-Eder, 2003). The overall results of the pollen analysis of samples 
TABLE 2. The nearest living relatives (NLR) of fossil taxa from leaf assemblage KRAM-P 225 and the mean annual temperature (MAT) ranges ( $\left.{ }^{\circ} \mathrm{C}\right)$ of NLR. Data on NLR and their MAT ranges based on Utescher and Mosbrugger (2017), and for Cercidiphyllum japonicum and Fagus hayatae on Fang et al. (2011).

\begin{tabular}{|c|c|c|c|}
\hline Fossil taxon & NLR of fossil taxon & $\begin{array}{l}\text { Lower limit of MAT } \\
\text { of NLR }\end{array}$ & $\begin{array}{l}\text { Upper limit of MAT } \\
\text { of NLR }\end{array}$ \\
\hline Acer tricuspidatum & $\begin{array}{l}\text { Acer section Rubra (Ac. rubrum, Ac. } \\
\text { saccharinum) }\end{array}$ & 3.40 & 23.90 \\
\hline Alnus ducalis & Alnus matsumurae* & -0.40 & 7.60 \\
\hline Betula cf. plioplatyptera & Betula sp. & -15.00 & 25.80 \\
\hline Betula subpubescens & Betula pubescens & -6.70 & 16.50 \\
\hline Carpinus grandis & Carpinus betulus & 5.30 & 17.60 \\
\hline Carpinus sp. & Carpinus sp. & 0.00 & 25.80 \\
\hline Carya serrifolia & Carya sp. & 4.40 & 26.60 \\
\hline cf. Cercidiphyllum crenatum & Cercidiphyllum japonicum & 2.00 & 18.20 \\
\hline Dicotylophyllum sp. 1 & - & - & - \\
\hline Fagus silesiaca & Fagus hayatae & 9.30 & 21.10 \\
\hline Gleditsia europaea sp. nov. & Gleditsia sp. & 5.70 & 21.70 \\
\hline Laria rueminiana & Reevesia sp. & 13.50 & 25.50 \\
\hline $\begin{array}{l}\text { Leguminophyllum kvacekii sp. } \\
\text { nov. }\end{array}$ & Leguminosae & - & - \\
\hline Myrica lignitum & Myrica sp. & -8.90 & 28.10 \\
\hline Phragmites oeningensis & Phragmites sp. & - & - \\
\hline Pinus sp. & Pinus sp. & -9.20 & 25.50 \\
\hline Potamogeton sp. & Potamogeton sp. & -15.00 & 23.50 \\
\hline Sequoia abietina & Sequoia sempervirens & 9.10 & 25.00 \\
\hline
\end{tabular}

* Alnus matsumurae is an outlier taxon, excluded from the calculation of MAT as it is a mountainous species, endemic to Japan.

taken from assemblage KRAM-P 225 generally correspond to the proposed late Miocene age of the leaf assemblage studied. The palynoflora is most similar in its composition to the spore-pollen spectra of the $X$ and $X I$ climatic phases distinguished by Ziembińska-Tworzydło (in Piwocki and Ziembińska-Tworzydło, 1997). Deposits bearing such assemblages accumulated during the late Serravalian and Tortonian. The studied palynoflora is also close in composition to assemblage KRAMP 218 (Worobiec and Worobiec, 2016). Thus, assemblage KRAM-P 225 could be either late Serravalian or Tortonian (latest middle Miocene and late Miocene).

\section{CONCLUSIONS}

From 132 specimens (37 slides with isolated leaf remains and 95 rock samples), 18 species from the genera Acer, Alnus, Betula, Carpinus, Carya, cf. Cercidiphyllum, Dicotylophyllum, Fagus, Gleditsia, Laria, Leguminophyllum, Myrica, Phragmites, Pinus, Potamogeton, and Sequoia were identified.
Two new fossil species were described: Gleditsia europaea sp. nov. G. Worobiec and Leguminophyllum kvacekii sp. nov. G. Worobiec.

Plant assemblage KRAM-P 225 reflects only local azonal wetland vegetation and most probably was formed in the fluvial sedimentary environment of a water body with stagnant or slowly flowing water, which is indicated by the presence of Potamogeton. The water body was surrounded by wetland (riparian) communities of a periodically flooded bottomland hardwood forest. In moist places it was probably dominated by Acer tricuspidatum, Betula cf. plioplatyptera, Betula subpubescens, Carpinus grandis, Carpinus sp., Carya serrifolia, cf. Cercidiphyllum crenatum, Gleditsia europaea sp. nov., Laria rueminiana, Myrica lignitum, Phragmites oeningensis, Pinus sp., and Sequoia abietina. Gleditsia europaea sp. nov. and Phragmites oeningensis most probably occupied the shore of the water body and were accompanied by Acer tricuspidatum, Carya serrifolia, and Myrica lignitum. In drier places, the bottomland vegetation was presumably mixed with more mesophytic taxa such as Carpinus 
grandis, Pinus sp. and Sequoia abietina. Riparian vegetation similar to assemblage KRAM-P 225 was common in the Miocene of the Polish Lowlands (Worobiec and Kasiński, 2009) and has much in common with the riparian communities of eastern and south-eastern North America (Wilen and Tiner, 1993; Hamel and Foti, 1995), and also probably with the riparian forests of central China (Wei et al., 2010). Taxa considered to be exclusively upland (mesophytic) seem to be completely absent from the discussed assemblage. However, Alnus ducalis, Fagus silesiaca, and some of other taxa may also have been components of mesophytic upland communities. The reconstruction of fossil vegetation based on the macroremains assemblage is in accordance with the results of pollen analysis.

Almost all of the taxa present in this leaf assemblage represent the warm temperate element. The nearest living relatives of those fossil species are found in warm temperate climate areas of the Northern Hemisphere. The presence of cf. Cercidiphyllum crenatum, Laria rueminiana, Gleditsia europaea sp. nov., and Sequoia abietina indicates favourable climatic conditions with presumably mild winters. The pollen analysis confirms a warm temperate climate and suggests moderately wet conditions. A mean annual temperature (MAT) range of $13.5^{\circ} \mathrm{C}-16.5^{\circ} \mathrm{C}$ is suggested on the basis of the coexistence approach (CA) method (Mosbrugger and Utescher, 1997). Reconstruction of palaeoprecipitation on the basis of azonal, wetland vegetation from Bełchatów seems unreliable.

The palaeoclimate of plant assemblage KRAMP 225 may have been comparable to the modernday climate of the areas of deciduous broad-leaved forest with a warm temperate, humid (often monsoonal), climate, classified as the Cfa type (warm temperate, fully humid, with a hot summer) in the Köppen-Geiger climate classification (Kottek et al., 2006).

The composition of leaf assemblage KRAM-P 225 , its geological setting, and the findings from its palynological analysis suggest a latest middle Miocene to late Miocene age.

\section{ACKNOWLEDGEMENTS}

The studies were supported by the W. Szafer Institute of Botany, Polish Academy of Sciences, Kraków, Poland through the statutory funds. We thank D. Zdebska, S. Florjan, and M. Wayda (former researchers of the Institute of Botany, Jagiellonian University, Kraków) for their help with fieldworks and collecting fossil leaves in the outcrop of the Bełchatów Lignite Mine.

\section{REFERENCES}

Adanson, M. 1763. Familles des Plantes. Vincent, Paris. https://doi.org/10.5962/bhl.title.271

APG IV, 2016. An update of the Angiosperm Phylogeny Group classification for the orders and families of flowering plants: APG IV. Botanical Journal of the Linnean Society, 181:1-20. https://doi.org/10.1111/boj.12385

Barclay, R.S., Wilf, P., Dilcher, D.L., and Mcelwain, J.C. 2017. The Cuticle Database Project. Accessed 14 September 2017. The Earth and Environmental Systems Institute, Pennsylvania State University, State College, Pennsylvania, USA. http:// cuticledb.eesi.psu.edu/

Barnhart, J.H. 1895. Family nomenclature. Bulletin of the Torrey Botanical Club, 22:1-24. https:// doi.org/10.2307/2485402

Behrensmeyer, A.K. and Hook, R.W. 1992. Paleoenvironmental context and taphonomic models, p. 15-136. In Behrensmeyer, A.K., Damuth, J.D., Di Michele, W.A., Potts, R., Sues, H.-D., and Wing, S.L. (eds.), Terrestrial Ecosystems Through Time: Evolutionary Paleoecology of Terrestrial Plants and Animals. University Chicago Press, Chicago.

Bonpland, A., von Humboldt, A., and Kunth, K.S. 1817. Nova Genera et Species Plantarum Quas in Peregrinatione ad Plagam Aequinoctialem Orbis Novi Collegerunt, Descripserunt, Partim Adumbraverunt Amat. Bonpland et Alex. de Humboldt. Ex Schedis Autographis Amati Bonplandi in Ordinem Digessit Carol. Sigismund. Kunth. Accedunt Tabulae Aeri Incisae, et Alexandri de Humboldt Notationes ad Geographiam Plantarum Spectantes. Sumtibus Librariae graeco-latino-germanicae, Lutetiae Parisiorum. https://doi.org/10.5962/bhl.title.640 
Box, E.O. and Fujiwara, K. 2013. Vegetation types and their broad-scale distribution, p. 455-485. In Van der Maarel, E. and Franklin, J. (eds.), Vegetation Ecology, Second Edition. John Wiley \& Sons, Chichester. https://doi.org/10.1002/9781118452592.ch15

Box, E.O. and Fujiwara, K. 2015. Warm-temperate deciduous forests: concept and global overview, p. 7-26. In Box, E.O. and Fujiwara, K. (eds.), Warm-Temperate Deciduous Forests around the Northern Hemisphere. Geobotany Studies (Basics, Methods and Case Studies). Springer, Cham. https://doi.org/10.1007/978-3-319-01261-2_2

Brinson, M.M., Swift, B.L., Plantico, R.C., and Barclay, J.S. 1981. Riparian Ecosystems: Their Ecology and Status. US Fish and Wildlife Service. Biological Services Program Report FWS/ OBS 81/17.

Burchart, J., Kasza, L., and Lorenc, S. 1988. Fission-track zircon dating of tuffitic intercalations (Tonstein) in the Brown-Coal Mine "Bełchatów." Bulletin of the Polish Academy of Sciences, Earth Sciences, 36:281-286.

Cantino, P.D., Doyle, J.A., Graham, S.W., Judd, W.S., Olmstead, R.G., Soltis, D.E., Soltis, P.S., and Donoghue, M.J. 2007. Towards a phylogenetic nomenclature of Tracheophyta. Taxon, 56:822-846. https://doi.org/10.2307/25065864

Chase, M.W. and Reveal, J.L. 2009. A phylogenetic classification of the land plants to accompany APG III. Botanical Journal of the Linnean Society, 161:122-127. https://doi.org/ 10.1111/j.1095-8339.2009.01002.x

Christenhusz, M., Reveal, J., Farjon, A., Gardner, M.F., Mill, R.R., and Chase, M.W. 2011. A new classification and linear sequence of extant gymnosperms. Phytotaxa, 19:55-70. https:// doi.org/10.11646/phytotaxa.19.1.3

Cooper, D.J. and Merritt, D.M. 2012. Assessing the Water Needs of Riparian and Wetland Vegetation in the Western United States. Gen. Tech. Rep. RMRS-GTR-282. Fort Collins, CO. U.S. Department of Agriculture, Forest Service, Rocky Mountain Research Station. https:// doi.org/10.2737/RMRS-GTR-282

Czarnecki, L., Frankowski, R., and Kuszneruk, J. 1992. Syntetyczny profil litostratygraficzny utworów trzeciorzędu złoża "Bełchatów," p. 19-23. In Lipiarski, I. (ed.), Materiały XV Sympozjum "Geologia Formacji Węglonośnych Polski”. Wydawnictwa AGH, Kraków. (in Polish)

Daghlian, C.P. 1981. A review of the fossil record of monocotyledons. The Botanical Review, 47:517-555. https://doi.org/10.1007/BF02860540

de Candolle, A.P. and Perleb, K.J. 1818. Versuch über die Arzneikräfte der Pflanzen: verglichen mit den äußern Formen und der natürlichen Klasseneintheilung derselben. Von Aug. Pyr. de Candolle. Nach der 2. franz. Aufl. übers. u. mit Zusätzen u. Anm. begleitet von Karl Julius Perleb. Sauerländer, Aarau.

de Saporta, G. 1865. Études sur la végétation du sud-est de la France à l'époque tertiaire. Annales des Sciences Naturelles, Botanique, 5:5-264.

de Saporta, G. 1894. Flore Fossile du Portugal : Nouvelles Contributions à la Flore Mésozoïque; Accompagnées d'une Notice Stratigraphique par Paul Choffat. Impr. de l'Académie royale des sciences, Lisbonne.

Dilcher, D.L. 1974. Approaches to the identification of angiosperm leaf remains. The Botanical Review, 40:1-157. https://doi.org/10.1007/BF02860067

Dumortier, B.-C. 1829. Analyse des Familles des Plantes, avec I'Indication des Principaux Genres qui s'y Rattachent. Impr. de J. Casterman aîné, Tournay. https://doi.org/10.5962/ bhl.title.443

Dyjor, S., Kvaček, Z., Łańcucka-Środoniowa, M., Pyszyński, W., Sadowska, A., and Zastawniak, E. 1992. The younger Tertiary deposits in the Gozdnica region (SW Poland) in the light of recent palaeobotanical research. Polish Botanical Studies, 3:3-129.

Elliott, S.J., Grettenberger, C.L., Donovan, M.P., Wilf, P., Walter, R.C., and Merritts, D.J. 2016. Riparian and valley-margin hardwood species of pre-colonial Piedmont forests: a preliminary study of subfossil leaves from White Clay Creek, southeastern Pennsylvania, USA. Palaeontologia Electronica, 19.1.2A:1-26. https://doi.org/10.26879/589

Ellis, B., Daly, D.C., Hickey, L.J., Johnson, K.R., Mitchell, J.D., Wilf, P., and Wing, S.L. 2009. Manual of Leaf Architecture. The New York Botanical Garden Press, Cornell University Press, Ithaca.

Endlicher, S. 1847. Synopsis Coniferarum. Apud Scheitlin \& Zollikofer, Sangalli. https://doi.org/ 10.5962/bhl.title.15336 
Engler, A. 1907. Syllabus der pflanzenfamilien: eine übersicht über das gesamte pflanzensystem mit berücksichtigung der medizinal- und nutzpflanzen, nebst einer übersicht über die florenreiche und florengebiete der erde, über spezielle und medizinisch-pharmazeutische botanik. Gebrüder Borntraeger, Berlin.

Escalup-Bassi, A. 1971. Sur deux empreintes des grès à sables d'Anjou. Comptes Rendus du Congrès des Sociétés Savantes de Paris et des Départements. Section des Sciences, 94:93-98.

Fang, J., Wang, Z., and Tang, Z. (eds.) 2011. Atlas of Woody Plants in China: Distribution and Climate, Vol. 1. Springer Science \& Business Media, Heidelberg, Dordrecht, London, New York. https://doi.org/10.1007/978-3-642-15017-3_1

Farr, E.R. and Zijlstra, G. (eds.) 2018. Index Nominum Genericorum (Plantarum). Accessed January 2018. Botany Department, National Museum of Natural History, Smithsonian Institution, Washington, USA. http://botany.si.edu/ing/

Ferguson, D.K 1985. The origin of leaf-assemblages - new light on an old problem. Review of Palaeobotany and Palynology, 46:117-188. https://doi.org/10.1016/0034-6667(85)90041-7

Ferguson, D.K., Pingen, M., Zetter, R., and Hofmann, C.C. 1998. Advances in our knowledge of the Miocene plant assemblage from Kreuzau, Germany. Review of Palaeobotany and Palynology, 101:147-177. https://doi.org/10.1016/S0034-6667(97)00074-2

Gærtner, J. 1791. De Fructibus et Seminibus Plantarum. Volumen alterum. Continens Seminum Centurias Quinque Posteriores cum Tabulis AEneis, CL. Typis Guilielmi Henrici Schrammii, Tubingae. https://doi.org/10.5962/bhl.title.53838

Gastaldo, R.A., Ferguson, D.K., Walther, H., and Rabold, J.M. 1996. Criteria to distinguish parautochthonous leaves in Tertiary alluvial channel-fills. Review of Palaeobotany and Palynology, 91:1-21. https://doi.org/10.1016/0034-6667(95)00071-2

Gray, S.F. 1821. A Natural Arrangement of British Plants, According to Their Relations to Each Other, as Pointed out by Jussieu, de Candolle, Brown, \&c., Including Those Cultivated for Use, with an Introduction to Botany, in which the Terms Newly Introduced Are Explained, Illustrated by Figures. Baldwin, Cradock, and Joy, London. https://doi.org/10.5962/ bhl.title.43804

Greller, A.M. 2013. Climate and regional composition of deciduous forest in eastern North America and comparisons with some Asian forests. Botanica Pacifica, 2:3-18. https://doi.org/ 10.17581/bp.2013.02101

Grímsson, F., Zetter, R., Grimm, G.W., Pedersen, G.K., Pedersen, A.K., and Denk, T. 2015. Fagaceae pollen from the early Cenozoic of West Greenland: revisiting Engler's and Chaney's Arcto-Tertiary hypotheses. Plant Systematics and Evolution, 301:809-832. https:// doi.org/10.1007/s00606-014-1118-5

Hably, L. and Kovar-Eder, J. 1996. A representative leaf assemblage of the Pannonian Lake from Dozmat near Szombathely (Western Hungary), Upper Pannonian, Upper Miocene, p. 69-80. In Dudich, E. and Lobitzer, H. (eds.), Advances in Austrian - Hungarian Joint Geological Research. Geologische Bundesanstalt, Wien.

Hably, L. and Kvaček, Z. 1997. Early Pliocene plant megafossils from the volcanic area in West Hungary, p. 5-151. In Hably, L. (ed.), Early Pliocene Volcanic Environment, Flora and Fauna from Transdanubia, West Hungary. Hungarian Natural History Museum, Budapest.

Hably, L. and Kvaček, Z. 1998. Pliocene mesophytic forests surrounding crater lakes in western Hungary. Review of Palaeobotany and Palynology, 101:257-269. https://doi.org/10.1016/ S0034-6667(97)00077-8

Hamel, P.B. and Foti, T.L. 1995 (eds.) Bottomland Hardwoods of the Mississippi Alluvial Valley: Characteristics and Management of Natural Function, Structure, and Composition. Proceedings of a Symposium Held during the Natural Areas Conference Fayetteville, Arkansas, October 28, 1995. U.S. Department of Agriculture, Forest Service, Southern Research Station, Asheville, NC. General Technical Report SRS-42.

Hantke, R. 1954. Die fossile Flora der obermiozänen Oehninger-Fundstelle Schrotzburg (Schienerberg, Süd-Baden). Diss. Naturwiss. ETH Zürich. Denkschriften der Schweizerischen Naturforschenden Gesellschaft, 80(2):31-118. https://doi.org/10.3929/ethza-000093943

Haston, E., Richardson, J.E., Stevens, P.F., Chase, M.W., and Harris, D.J. 2009. The Linear Angiosperm Phylogeny Group (LAPG) III: a linear sequence of the families in APG III. Botanical Journal of the Linnean Society, 161:128-131. https://doi.org/10.1111/j.10958339.2009.01000.x 
Haynes, R.R., Les, D.H., and Holm-Nielsen, L.B. 1998. Potamogetonaceae, p. 408-415. In Kubitzki, K. (ed.), The Families and Genera of Vascular Plants. Volume IV. Flowering Plants, Monocotyledons. Alismatanae and Commelinanae (except Gramineae). Springer, Berlin, Heidelberg. https://doi.org/10.1007/978-3-662-03531-3

Heer, O. 1856. Die tertiäre Flora der Schweiz (Flora tertiaria Helvetiae), Vol. 2. J. WursterComp., Winterthur. https://doi.org/10.3931/e-rara-10496

Hickey, L.J. 1973. Classification of the architecture of dicotyledonous leaves. American Journal of Botany, 60:17-33. https://doi.org/10.2307/2441319

Hickey, L.J. 1979. A revised classification of the architecture of dicotyledonous leaves, p. 25-39. In Metcalfe, C.R. and Chalk, L. (eds.), Anatomy of the Dicotyledons. Volume 1. Systematic Anatomy of Leaf and Stem with a Brief History of the Subject (Second Edition). Clarendon Press, Oxford.

Hoffmann, J. and Schultes, H. 1852. Noms indigènes d'un choix de plantes du Japon et de la Chine, déterminés d'après les échantillons de l'herbier des Pays-Bas. Journal Asiatique : ou Recueil de Mémoires, d'Extraits et de Notices Relatifs à l'Histoire, à la Philosophie, aux Langues et à la Littérature des Peuples Orientaux, 4(20):257-370. https://doi.org/10.5962/ bhl.title.127444

Holý, F., Kvaček, Z., and Teodoridis, V. 2012. A review of the early Miocene mastixioid flora of the Kristina Mine at Hrádek nad Nisou in North Bohemia (The Czech Republic). Acta Musei Nationalis Pragae, Series B, Historia Naturalis, 68:53-118.

Hummel, A. 1991. The Pliocene leaf flora from Ruszów near Żary in Lower Silesia, south-west Poland. Part 2. (Betulaceae). Acta Palaeobotanica, 31:73-151.

Ilinskaya, I.A. 1964. Tortonskaya flora Svoshovitse (The Tortonian flora of Swoszowice). Trudy Botanicheskogo Instituta Akademii Nauk SSSR Series 8, Paleobotanika, 5:113-144.

Ilinskaya, I.A. 1968. Neogenovye flory Zakarpatskoi oblasti USSR (Neogene floras of the Transcarpathian Region of the U.S.S.R.). Izdatel'stvo Nauka, Leningrad.

IPNI (International Plant Names Index), 2018. Accessed January 2018. http://www.ipni.org

Jerzmańska, A. and Hałuszczak, A. 1986. Nowe stanowisko ryb słodkowodnych (Teleostei) z trzeciorzędu Polski (A new locality of Tertiary fresh-water fish fauna (Teleostei) in Poland). Przegląd Geologiczny, 34:25-27.

Jussieu, A.L. de 1789. Genera Plantarum: Secundum Ordines Naturales Disposita, Juxta Methodum in Horto Regio Parisiensi Exaratam, Anno M.DCC.LXXIV. Apud viduam Herissant et Theophilum Barrois, Parisiis. https://doi.org/10.5962/bhl.title.284

Knobloch, E. 1964. Haben Cinnamomum scheuchzeri Heer und Cinnamomum polymorphum (Al.Braun) Heer nomenklatorisch richtige Namen. Neues Jahrbuch für Geologie und Paläontologie, 10:597-603.

Knobloch, E. 1969. Tertiäre Floren von Mähren. Herausgegeben vom Moravské Muzeum, Brno in Zusammenarbeit mit dem Musejni Spolek, Brno.

Knobloch, E. and Kvaček, Z. 1976. Miozäne Blätterfloren vom Westrand der Böhmischen Masse. Rozpravy Ustředního Ustavu Geologického, 42:1-131.

Kottek, M., Grieser, J., Beck, C., Rudolf, B., and Rubel, F. 2006. World map of the KöppenGeiger climate classification updated. Meteorologische Zeitschrift, 15:259-263. https:// doi.org/10.1127/0941-2948/2006/0130

Kovar-Eder, J. 2003. Vegetation dynamics in Europe during the Neogene. Deinsea, 10:373-392.

Kovar-Eder, J. and Krainer, B. 1991. Flora und Sedimentologie der Fundstelle Reith bei Unterstorcha, Bezirk Feldbach in der Steiermark (Kirchberger Schotter, Pannonium C, Miozän). Jahrbuch der Geologischen Bundesanstalt, 134:737-771.

Kovar-Eder, J., Kvaček, Z., and Meller, B. 2001. Comparing early to middle Miocene floras and probable vegetation types of Oberdorf N Voitsberg (Austria), Bohemia (Czech Republic), and Wackersdorf (Germany). Review of Palaeobotany and Palynology, 114:83-125. https:// doi.org/10.1016/S0034-6667(00)00070-1

Kovar-Eder, J., Kvaček, Z., Zastawniak, E., Givulescu, R., Hably, L.,Mihajlovic, D., Teslenko, Y., and Walther, H. 1996. Floristic trends in the vegetation of the Paratethys surrounding areas during Neogene time, p. 395-413. In Bernor, R.L., Fahlbusch, V., and Mittmann, H.-W. (eds.), The Evolution of Western Eurasian Neogene Mammal Faunas. Columbia University Press, New York.

Kovar-Eder, J., Meller, B., and Zetter, R. 1998. Cercidiphyllum crenatum (Unger) R.W.Brown in der kohleführenden Abfolge von Oberdorf N Voitsberg, Steiermark. Mitteilungen des Referats für Geologie und Paläontologie Landesmuseum Joanneum, SH2:239-264. 
Kowalski, K. 1993. Neocometes Schaub and Zapfe, 1953 (Rodentia, Mammalia) from the Miocene of Belchatów (Poland). Acta Zoologica Cracoviensia, 36:259-265.

Kowalski, K. and Rzebik-Kowalska, B. 2002. Paleoecology of the Miocene fossil mammal fauna from Bełchatów (Poland). Acta Theriologica, 47:115-126. https://doi.org/10.1007/bf03192483

Kownas, S. 1956. Trzeciorzędowa flora z Dobrzynia nad Wisłą (Tertiary flora from Dobrzyń on the Vistula). Acta Geologica Polonica, 5:439-516.

Krajewska, K. 1998. Neogene leaf flora from Gnojna (Opole Prov., SW Poland). Acta Palaeobotanica, 38:25-85.

Kräusel, R. 1920. Nachträge zur Tertiärflora Schlesiens. I. Jahrbuch der Preussischen Geologischen Landesanstalt zu Berlin (für das Jahr 1918), 39(1):329-417.

Kräusel, R. and Weyland, H. 1959. Kritische Untersuchungen zur Kutikularanalyse tertiärer Blätter IV. Palaeontographica Abteilung B, 105:101-124.

Krüssmann, G. 1976. Handbuch der Laubgehölze. Band 2. Verlag Paul Parey, Berlin, Hamburg.

Krzyszkowski, D. and Winter, H. 1996. Stratigraphic position and sedimentary features of the Tertiary Uppermost Fluvial Member in the Kleszczów Graben, central Poland. Annales Societatis Geologorum Poloniae, 66:17-33.

Kvaček, Z. and Konzalová, M. 1996. Emended characteristics of Cercidiphyllum crenatum (Unger) R.W. Brown based on reproductive structures and pollen in situ. Palaeontographica Abteilung $B, 239: 147-155$.

Kvaček, Z., Teodoridis, V., and Gregor, H.J. 2008. The Pliocene leaf flora of Auenheim, Northern Alsace (France). Documenta Naturae, 155:1-108.

Kvaček, Z., Teodoridis, V., and Roiron, P. 2011. A forgotten Miocene mastixioid flora of Arjuzanx (Landes, SW France). Palaeontographica Abteilung B, 285:3-111. https://doi.org/10.1127/ palb/285/2011/3

Kvaček, Z. and Walther, H. 1991. Revision der mitteleuropäischen tertiären Fagaceen nach blattepidermalen Charakteristiken. IV. Teil Fagus Linné. Feddes Repertorium, 102:471-534. https://doi.org/10.1002/fedr.19911020702

Les, D.H. and Sheridan, D.J. 1990. Biochemical heterophylly and flavonoid evolution in North American Potamogeton (Potamogetonaceae). American Journal of Botany, 77:453-465. https://doi.org/10.2307/2444379

Lichvar, R.W. 2013. The National Wetland Plant List: 2013 wetland ratings. Phytoneuron, 49:1241.

Lindley, J. 1830. An Introduction to the Natural System of Botany: or, a Systematic View of the Organisation, Natural Affinities, and Geographical Distribution, of the Whole Vegetable Kingdom; Together with the Uses of the Most Important Species in Medicine, the Arts, and Rural or Domestic Economy. Longman, Rees, Orme, Brown, and Green, London. https:// doi.org/10.5962/bhl.title.7551

Lindley, J. 1836. A Natural System of Botany, or, a Systematic View of the Organization, Natural Affinities, and Geographical Distribution, of the Whole Vegetable Kingdom; Together with the Uses of the Most Important Species in Medicine, the Arts, and Rural or Domestic Economy. Second Edition, with Numerous Additions and Corrections, and a Complete List of Genera, with Their Synonyms. Longman, Rees, Orme, Brown, Green, and Longman, London. https:// doi.org/10.5962/bhl.title.130142

Linnaeus, C. 1753. Species Plantarum: Exhibentes Plantas Rite Cognitas, ad Genera Relates, cum Differentiis Specificis, Nominibus Trivialibus, Synonymis Selectis, Locis Natalibus, Secundum Systema Sexuale Digestas. Tomus I, II. Holmiae: Impensis Laurentii Salvii, (Tomus I). https://doi.org/10.5962/bhl.title.669

Mai, D.H. 1995. Tertiäre Vegetationsgeschichte Europas. Gustav Fischer Verlag, Jena, Stuttgart, New York.

Mai, D.H. and Walther, H. 1978. Die Floren der Haselbacher Serie im Weisselster-Becken (Bezirk Leipzig, DDR). Abhandlungen des Staatlichen Museums für Mineralogie und Geologie zu Dresden, 28:1-200.

Mai, D.H. and Walther, H. 1988. Die pliozänen Floren von Thüringen, Deutsche Demokratische Republik. Quartärpaläontologie, 7:55-297.

Matl, K. 2000. Wybrane elementy budowy geologicznej złoża Bełchatów (Selected elements of geological structure of the Bełchatów deposit), p. 11-19. In Słomka, T. and Wagner, M. (eds.), Charakter petrograficzny i warunki sedymentacji wybranych kompleksów litologicznych z profilu miocenu w złożu węgla brunatnego Bełchatów (Petrological Studies and 
Sedimentological Conditions of Select Lithologic Series in Miocene from Bełchatów Lignite Deposit, Poland). Komisja Nauk Geologicznych PAN, oddział w Krakowie, Prace Geologiczne.

Miller, P. 1754. The Gardeners Dictionary. Containing the Methods of Cultivating and Improving all Sorts of Trees, Plants, and Flowers, for the Kitchen, Fruit, and Pleasure Gardens; as Also Those Which are Used in Medicine. With Directions for the Culture of Vineyards, and Making of Wine in England. In Which Likewise are Included the Practical Parts of Husbandry. Abridged from the Last Folio Edition by the Author, Philip Miller. Printed for the author and sold by John and James Rivington, London. https://doi.org/10.5962/bhl.title.79061

Moore, P.D., Webb, J.A., and Collinson, M.E. 1991. Pollen Analysis. Blackwell, Oxford.

Mosbrugger, V. and Utescher, T. 1997. The coexistence approach-a method for quantitative reconstructions of Tertiary terrestrial palaeoclimate data using plant fossils. Palaeogeography, Palaeoclimatology, Palaeoecology, 134:61-86. https://doi.org/10.1016/ S0031-0182(96)00154-X

Němejc, F. 1949. The plant impressions of the Tertiary accumulations (Neogene) in Central Bohemia. Studia Botanica Čechoslovaca, 10:14-103.

Nuttall, T. 1818. The Genera of North American Plants, and a Catalogue of the Species, to the Year 1817. Printed for the author by D. Heartt, Philadelphia. https://doi.org/10.5962/ bhl.title. 290

Otto, A, Simoneit, B.R.T., Lesiak, M., Wilde, V., and Worobiec, G. 2001. Resin and wax biomarkers preserved in Miocene Cupressaceae s. I. from Bełchatów and Lipnica Wielka, Poland. Acta Palaeobotanica, 41:195-206.

Palamarev, E.H. and Petkova, A.S. 1987. Les Fossiles de Bulgarie, VIII/1. La Macroflore du Sarmatien. L'Académie Bulgare des Sciences, Sophia.

Piwocki, M. and Ziembińska-Tworzydło, M. 1997. Neogene of the Polish Lowlands lithostratigraphy and pollen-spore zones. Geological Quarterly, 41:21-40.

Prista, G.A., Agostinho, R.J., and Cachão, M.A. 2015. Observing the past to better understand the future: a synthesis of the Neogene climate in Europe and its perspectives on present climate change. Open Geosciences, 7:65-83. https://doi.org/10.1515/geo-2015-0007

Procházka, M. and Bůžek, Č. 1975. Maple leaves from the Tertiary of North Bohemia. Rozpravy Ustrědního Ústavu Geologického, 41:1-86.

Raniecka-Bobrowska, J. 1954. Trzeciorzędowa flora liściowa z Konina (Tertiary foliaceous flora from Konin). Biuletyn Instytutu Geologicznego, 71:5-40.

Reed, P.B., Jr. 1988. National List of Plant Species That Occur in Wetlands: National Summary. U.S. Fish and Wildlife Service. Biological Report, 88(24).

Roy, D.F. 1966. Silvical Characteristics of Redwood (Sequoia sempervirens (D. Don) Endl.). U.S. Forest Service Research Paper PSW-28, Berkeley, CA: Pacific Southwest Forest and Range Experiment Station, Forest Service, U.S. Department of Agriculture.

Rudolphi, F.C.L. 1830. Systema Orbis Vegetabilium Quod Gratiosi Medicorum Ordinis Consensu et Auctoritate Dissertatione Inaugurali ad Summos in Medicina et Chirurgia Honores Rite Impetrandos. PhD dissertation. Gryphiae, Typis F. Guil. Kunike. https://doi.org/10.5962/ bhl.title.129917

Rzebik-Kowalska, B. and Kowalski, K. 2001. The northernmost fossil locality of fruit bats (Megachiroptera, Mammalia) in the Miocene of Bełchatów (Poland). Acta Zoologica Cracoviensa, 44:59-63.

Schnabel, A., McDonel, P.E., and Wendel, J.F. 2003. Phylogenetic relationships in Gleditsia (Leguminosae) based on ITS sequences. American Journal of Botany, 90:310-320. https:// doi.org/10.3732/ajb.90.2.310

Schneider, W. 1992. Floral successions in Miocene swamps and bogs of Central Europe. Zeitschrift für Geologische Wissenschaften, 20:555-570.

Schnitzler, A., Hale, B.W., and Alsum, E. 2005. Biodiversity of floodplain forests in Europe and eastern North America: a comparative study of the Rhine and Mississippi Valleys. Biodiversity and Conservation, 14:97-117. https://doi.org/10.1007/s10531-005-4056-2

Spicer, R.A. 1980. The importance of depositional sorting to the biostratigraphy of plant megafossils, p. 171-183. In Dilcher, D.L. and Taylor, T.N. (eds.), Biostratigraphy of Fossil Plants: Successional and Paleoecological Analyses. Dowden, Hutchinson and Ross (New York), Stroudsburg.

Stizenberger, E. 1851. Übersicht der Versteinerungen des Grossherzogtums Baden. Verlag der Universitäts-Buchhandlung von J. Diernfellner, Freiburg. 
Stuchlik, L., Szynkiewicz, A., Łańcucka-Środoniowa, M., and Zastawniak, E. 1990. Wyniki dotychczasowych badań paleobotanicznych trzeciorzędowych węgli brunatnych złoża "Bełchatów" (Results of the hitherto palaeobotanical investigations of the Tertiary brown coal bed "Bełchatów" (Central Poland). Acta Palaeobotanica, 30:259-305.

Stults, D.Z. and Axsmith, B. 2015. New plant fossil records and paleoclimate analyses of the late Pliocene Citronelle Formation flora, U.S. Gulf Coast. Palaeontologia Electronica, 18.3.47A:135. https://doi.org/10.26879/550 palaeo-electronica.org/content/in-press/1318-citronelle-flora-climate

Stworzewicz, E. 1995. Miocene land snails from Bełchatów (Central Poland), I. Cyclophoridae, Pomatiasidae (Gastropoda Prosobranchia). Paläontologische Zeitschrift, 69:19-30. https:// doi.org/10.1007/bf02985971

Stworzewicz, E. and Szynkiewicz, A. 1988. Mioceńskie ślimaki lądowe ze wschodniej części KWB Bełchatów (Miocene land snails from eastern part of Bełchatów Brown Coal delf). Geological Quarterly, 32:655-661.

Szynkiewicz, A. 2000. Wiek węgla brunatnego na tle pozycji geologicznej badanych próbek (KWB „Bełchatów”) (Age of the brown coal deposits from Bełchatów lignite mine (Central Poland)). Przegląd Geologiczny, 48:1038-1044.

Teodoridis, V. 2002. Tertiary flora and vegetation of the Hlavačov gravel and sand and the surroundings of Holedeč in the Most Basin (Czech Republic). Acta Musei Nationalis Pragae series $B$ - Historia Naturalis, 57:103-140.

Teodoridis, V. 2007. Revision of Potamogeton fossils from the Most Basin and their palaeoecological significance (Early Miocene, Czech Republic). Bulletin of Geosciences, 82:409-418. https://doi.org/10.3140/bull.geosci.2007.04.409

Teodoridis, V., Kvaček, Z., Sami, M., Utescher, T., and Martinetto, E. 2015. Palaeoenvironmental analysis of the Messinian macrofossil floras of Tossignano and Monte Tondo (Vena del Gesso Basin, Romagna Apennines, Northern Italy). Acta Musei Nationalis Pragae series B Historia Naturalis, 71:249-292.

Tepley, A.J., Cohen, J.G., and Huberty, L. 2004. Natural Community Abstract for Floodplain Forest. Michigan Natural Features Inventory, Lansing, MI.

Theriot, R.F. 1993. Flood Tolerance of Plant Species in Bottomland Forests of the Southeastern United States. U.S Army Corps of Engineers, Wetlands Research Program Technical Report WRP-DE-6. Army Engineer Waterways Experiment Station, Vicksburg.

Tiner, R.W. 1993. Using plants as indicators of wetland. Proceedings of the Academy of Natural Sciences of Philadelphia, 144:240-253.

USDA Plants Database 2017. Gleditsia aquatica Marsh. Water Locust. Accessed 14 September 2017. United States Department of Agriculture, Natural Resources Conservation Service. https://plants.usda.gov/java/

Utescher, T. and Mosbrugger, V. 2017. The Palaeoflora Database. Accessed September 15, 2017. http://www.palaeoflora.de/

Velitzelos, D., Bouchal, J.M., and Denk, T. 2014. Review of the Cenozoic floras and vegetation of Greece. Review of Palaeobotany and Palynology, 204:56-117. https://doi.org/10.1016/ j.revpalbo.2014.02.006

von Berchtold, F. and Presl, J.S. 1823. O přirozenosti rostlin aneb rostlinář, obsahugjcj popsánj a wyobrazenj rostlin podlé rádů priirozených zpořádané pfirozenych, s zewrubným wyznamenánjm wlastnostj, užitečnosti a škodliwosti, obzwlástě wywodin a zlodin, spůsobu wydobýwánj, poslednjch dobroty a porušenosti neygistěgšjho poznánj a skaušenj, též spůsobu užitecných sázenj chowánj a rozmnožwánj. Ustanowený pro lékaře, hogiče, hospodáře, umělce, remeslnjky a wychowatcle. Jos. Krause, Praha.

von Siebold, P.F. and Zuccarini, J.G. 1846. Florae Japonicae familae naturales, adjectis generum et specierum exemplis selectis. Sectio altera. Plantae dicotyledoneae et monocotyledonae. Abhandlungen der Mathematisch-Physikalischen Classe der Königlich Bayerischen Akademie der Wissenschaften, 4:123-240.

von Trinius, C.B. 1820. Fundamenta Agrostographiae, sive Theoria Contructionis Floris Graminei; Adjecta Synopsi Generum Graminum Hucusque Cognitorum. Apud J.G. Heubner, Viennae. https://doi.org/10.5962/bhl.title.15521

Walther, H. 1972. Studien über tertiäre Acer Mitteleuropas. Abhandlungen des Staatlichen Museums für Mineralogie und Geologie zu Dresden, 19:1-309.

Walther, H. 1994. Entwicklung der Fagaceae (Buchengewächse) im Tertiär Mitteleuropas. Berichte der Naturforschenden Gesellschaft der Oberlausitz, 3:27- 42. 
Walther, H. and Zastawniak, E. 1991. Fagaceae from Sośnica and Malczyce (near Wrocław, Poland). A revision of original materials by Goeppert 1852 and 1855 and a study of new collections. Acta Palaeobotanica, 31:153-199.

Wang, Q. 2012. Nomenclatural notes on Leguminosites and several taxonomically relevant names (fossil Leguminosae). Taxon, 61:871-877. https://doi.org/10.1002/tax.614014

Watson, F.D. 1993. Sequoia Endlicher, p. 401-402. In Flora of North America Editorial Committee (eds.), 1993+. Flora of North America North of Mexico. 19+ vols. New York and Oxford.

Wegierek, P. 1995. Dwa nowe stanowiska owadów trzeciorzędowych w Polsce. Przegląd Geologiczny, 43:660-661.

Wei, X.Z., Jiang, M.X., Huang, H.D., Yang, J.Y., and Yu, J. 2010. Relationships between environment and mountain riparian plant communities associated with two rare Tertiary-relict tree species, Euptelea pleiospermum (Eupteleaceae) and Cercidiphyllum japonicum (Cercidiphyllaceae). Flora, 205:841-852. https://doi.org/10.1016/j.flora.2010.04.003

Wilczyński, R., 1992. Dotychczasowe wyniki badań podstawowych serii poznańskiej w świetle geologiczno-inżynierskich problemów prowadzenia robót górniczych w KWB "Bełchatów" (The hitherto existing results of the Poznań suite in the light of geological-engineering problems of carrying mining works in the "Bełchatów" brown coal open mine). Acta Universitatis Wratislaviensis, 1354, Prace Geologiczno-Mineralogiczne, 24:91-108.

Wilen, B.O. and Tiner, R.W. 1993. Wetlands of the United States, p. 515-636. In Whigham, D.F., Dykyjová, D., and Hejný, S. (eds.), Wetlands of the World I: Inventory, Ecology and Management. Springer, Dordrecht. https://doi.org/10.1007/978-94-015-8212-4_12

Wilkinson, H.P. 1979. The plant surface (mainly leaf), p. 97-166. In Metcalfe, C.R. and Chalk, L. (eds.), Anatomy of the Dicotyledons, Volume I. Systematic Anatomy of Leaf and Stem, with a Brief History of the Subject. Second Edition. Clarendon Press, Oxford.

Wójcicki, J.J. and Zastawniak, E. 1998. Trapa srodoniana, a new fossil species from the Pliocene of Bełchatów (Middle Poland). Acta Palaeobotanica, 38:167-174.

Worobiec, E. and Worobiec, G. 2005. Leaves and pollen of bamboos from the Polish Neogene. Review of Palaeobotany and Palynology, 133:39-50. https://doi.org/10.1016/ j.revpalbo.2004.08.004

Worobiec, E. and Worobiec, G. 2008. Kopalne zygospory glonów Zygnemataceae (Chlorophyta) z osadów górnego miocenu KWB „Bełchatów” (Fossil zygospores of Zygnemataceae algae (Chlorophyta) from the Upper Miocene of the Bełchatów Lignite Mine). Przegląd Geologiczny, 56:1000-1004.

Worobiec, E. and Worobiec, G. 2016. Miocene palynoflora from the KRAM-P 218 leaf assemblage from the Bełchatów Lignite Mine (Central Poland). Acta Palaeobotanica, 56: 499-517. https://doi.org/10.1515/acpa-2016-0012

Worobiec, G. 2003a. An improved technique for separation, bleaching and preparation of slides from fossil leaf compressions. Review of Palaeobotany and Palynology, 126:1-5. https:// doi.org/10.1016/S0034-6667(03)00008-3

Worobiec, G. 2003b. New fossil floras from Neogene deposits in the Bełchatów Lignite Mine. Acta Palaeobotanica, Suppl. 3:1-133.

Worobiec, G. 2007. Laurus abchasica (Kolakovsky \& Shakryl) Ferguson from the Neogene of the Bełchatów Lignite Mine (Central Poland). Acta Palaeobotanica, 47:203-215.

Worobiec, G. 2014. Late Neogene leaf assemblage from Bełchatów Lignite Mine (central Poland). Acta Palaeobotanica, 54:249-277. https://doi.org/10.2478/acpa-2014-0009

Worobiec, G. and Kasiński, J. 2009. Dispersed cuticles from the Neogene Ruja lignite deposit near Legnica, Lower Silesia, Poland. Acta Palaeobotanica, 49:135-191.

Worobiec, G. and Lesiak, M. 1998. Plant megafossils from the Neogene deposits of Stawek-1A (Bełchatów, Middle Poland). Review of Palaeobotany and Palynology, 101:179-208. https:// doi.org/10.1016/S0034-6667(97)00075-4

Worobiec, G. and Szynkiewicz, A. 2007. Betulaceae leaves in Miocene deposits of the Bełchatów Lignite Mine (Central Poland). Review of Palaeobotany and Palynology, 147:2859. https://doi.org/10.1016/j.revpalbo.2007.06.001

Worobiec, G. and Szynkiewicz, A. 2016. Neogene wetland vegetation based on a leaf assemblage from the Bełchatów Lignite Mine (Central Poland). Acta Palaeobotanica, 56:441497. https://doi.org/10.1515/acpa-2016-0015 
Worobiec, G., Worobiec, E., and Kasiński, J. 2008. Plant assemblages of the drill cores from the Neogene Ruja lignite deposit near Legnica (Lower Silesia, Poland). Acta Palaeobotanica, 48:191-275.

Worobiec, G., Worobiec, E., and Kvaček, Z. 2010. Neogene leaf morphotaxa of Malvaceae s.I. in Europe. International Journal of Plant Sciences, 171:892-914. https://doi.org/10.1086/ 655866

Worobiec, G., Worobiec, E., and Szynkiewicz, A. 2012. Plant assemblage from the Upper Miocene deposits of the Bełchatów Lignite Mine (Central Poland). Acta Palaeobotanica, 52:369-413.

Yabe, A. 2008. Plant megafossil assemblage from the Lower Miocene Ito-o Formation, Fukui Prefecture, Central Japan. Memoir of the Fukui Prefectural Dinosaur Museum, 7:1-24.

Zastawniak, E. 1972. Pliocene leaf flora from Domański Wierch near Czarny Dunajec (Western Carpathians, Poland). Acta Palaeobotanica, 13:3-73.

Zastawniak, E. 1980. Sarmatian leaf flora from the southern margin of the Holy Cross Mts. (South Poland). Prace Muzeum Ziemi, 33:39-108.

Zastawniak, E. and Walther, H. 1998. Betulaceae from Sośnica near Wrocław (Poland) - a revision of Goeppert's original materials and study of more recent collections. Acta Palaeobotanica, 38:87-145.

Zidianakis, G., Iliopoulos, G., Zelilidis, A., and Kovar-Eder, J. 2015. Myrica from the plant assemblage of Pitsidia (Crete, late Miocene): putting the puzzle together. Palaeontographica Abteilung B, 293:149-171. https://doi.org/10.1127/palb/293/2015/149

Ziembińska-Tworzydło, M. 1966. Stratygrafia osadów trzeciorzędowych w złożu "Bełchatów" na podstawie analizy sporowo-pyłkowej (Stratigraphy of Tertiary sediments of the "Bełchatów" bed on the basis of sporo-pollen analysis). Geological Quarterly, 10:1117-1118. 